Cite as: B. Israelow et al., Sci. Immunol. 10.1126/sciimmunol.abl4509 (2021).

\title{
CORONAVIRUS
}

\section{Adaptive immune determinants of viral clearance and protection in mouse models of SARS-CoV-2}

\author{
Benjamin Israelow ${ }^{1,2}$, Tianyang Mao', Jonathan Klein', Eric Song1, Bridget Menasche ${ }^{3}$, Saad B. Omer ${ }^{2,4,5}$, Akiko \\ Iwasaki ${ }^{1,6 *}$ \\ ${ }^{1}$ Department of Immunobiology, Yale University School of Medicine, New Haven, CT, USA. ${ }^{2}$ Department of Medicine, Section of Infectious Diseases, Yale University School of \\ Medicine, New Haven, CT, USA. ${ }^{3}$ Department of Laboratory Medicine, Yale University School of Medicine, New Haven, CT, USA. ${ }^{4}$ Department of Epidemiology of Microbial \\ Diseases, Yale School of Public Health, New Haven, CT, USA. ${ }^{5}$ Yale Institute for Global Health, Yale University, New Haven, CT, USA. ${ }^{6}$ Howard Hughes Medical Institute, \\ Chevy Chase, MD, USA \\ *Corresponding author. Email: Akiko.Iwasaki@yale.edu
}

Severe acute respiratory syndrome coronavirus 2 (SARS-CoV-2) has caused more than 160 million infections and more than 3 million deaths worldwide. While effective vaccines are currently being deployed, the adaptive immune determinants that promote viral clearance and confer protection remain poorly defined. Using mouse models of SARS-CoV-2, we demonstrate that both humoral and cellular adaptive immunity contribute to viral clearance in the setting of primary infection. Furthermore, we find that either convalescent mice or mice that receive mRNA vaccination are protected from both homologous infection and infection with a variant of concern, B.1.351. Additionally, we find this protection largely mediated by antibody response and not cellular immunity. These results highlight the in vivo protective capacity of antibodies generated to both vaccine and natural infection.

\section{INTRODUCTION}

The development of adaptive immune responses to natural SARS-CoV-2 infection as well as to SARS-CoV-2 vaccination in humans has been well characterized (1-4). Additional studies have reported that vaccine-induced or natural-infection-induced immunity in animal models including non-human primates (5-9), mice $(10,11)$, and hamsters (12), is sufficient for protection from homologous SARS-CoV-2 challenge. Phase III vaccine clinical trials as well as post-marketing vaccine effectiveness studies provide evidence of the development of protective immunity in humans $(13,14)$. Epidemiologic studies of natural infection have also indicated that adaptive immune memory is sufficient to protect against SARS-CoV-2 reinfection in most cases (15). However, few of these studies have identified the essential correlates of protective adaptive immunity. The relative contributions of cellular and humoral immunity in the clearance of SARS-CoV-2 and protection from reinfection remain poorly defined in both vaccine-induced immunity and natural infection-induced immunity. Importantly, questions regarding the degree to which $\mathrm{T}$ cell-mediated immune memory may compensate for waning antibody-mediated immunity have become even more critical given the emergence of viral variants of concern (VOC) that evade neutralizing antibody responses from both vaccinated and convalescent individuals (16-19).

\section{RESULTS \\ Immunodeficient mice develop chronic SARS-CoV-2 infection}

To address these questions surrounding the immunological determinants of protection from SARS-CoV-2 infection, we utilized our previously reported mouse model (20), which employs in vivo transduction of the mouse respiratory tract with adeno-associated virus expressing human ACE2 (AAVhACE2) (Fig. 1A). This model enables us to infect mice of varying genetic backgrounds to identify how deficiencies in specific components of the adaptive immune system affect clearance of and protection from SARS-CoV-2. First, to assess whether adaptive immunity is required for clearance of SARS-CoV-2 upon primary infection, we administered AAVhACE2 to Rag1 ${ }^{-/-}$mice, which do not produce any mature B or T lymphocytes (21). These mice were infected with $1 \times 10^{6}$ plaque-forming units (PFU) of SARS-CoV-2 WA1 strain (USAWA1/2020). Interestingly, we found that these mice became persistently infected and were unable to clear the virus, maintaining stable levels of viral RNA and infectious virus for greater than 14 days post-infection (DPI) in lung tissues (Fig. $1 \mathrm{~B}, \mathrm{C}$ ). This is in contrast to $\mathrm{C} 57 \mathrm{Bl} / 6 \mathrm{~J}$ (WT) mice, which cleared the virus by 7 DPI as indicated by loss of culturable SARS-CoV-2 by plaque assay and reduction of viral RNA by RT-PCR (Fig. 1B, C). While our previous work suggested that innate immunity played a minimal role in clearing SARSCoV-2 during acute infection in mice (20), these data confirm 
that in the absence of adaptive immunity, the innate immune responses are insufficient to clear acute SARS-CoV-2 infection. These results are consistent with case reports describing patients with either genetic or acquired defects in their adaptive immunity who are unable to clear SARS-CoV-2 (22-24). Next, to assess the requirement of humoral immunity in SARS-CoV-2 clearance, we infected AAV-hACE2 $\mu \mathrm{MT}$ mice (mice deficient in B lymphocytes) (25) and found that these mice retained the ability to clear SARS-CoV-2. However, it occurred more slowly than in WT infected mice, as indicated by the presence of infectious virus at 7 DPI ( $4 / 8$ vs $0 / 4)$ and $17 x$ more viral RNA at 14 DPI (Fig. 1B, C). These results suggest that cellular immunity is sufficient for viral clearance in the setting of acute infection, even in the absence of humoral responses. However, humoral immunity is not completely redundant in its contribution to viral clearance.

To further delineate the role of $\mathrm{T}$ cell subsets required for viral clearance, we infected AAV-hACE2 WT mice that were treated with $\alpha \mathrm{CD} 4, \alpha \mathrm{CD} 8$, or $\alpha \mathrm{CD} 4 / \alpha \mathrm{CD} 8$ depleting antibodies (Fig. 2A). We found that depletion of $\mathrm{CD} 8^{+} \mathrm{T}$ cells alone inhibited viral clearance, as indicated by 7.4x more RNA than PBS control at 14 DPI (Fig. 2B). We also found that depletion of $\mathrm{CD}_{4}^{+} \mathrm{T}$ cells alone inhibited viral clearance by $6.2 \mathrm{x}$ compared to control at 14 DPI (Fig. 2B). Depletion of both CD4 ${ }^{+}$ and $\mathrm{CD}^{+} \mathrm{T}$ cells had a synergistic effect leading to a $31 \mathrm{x}$ increase in viral RNA persistence at 14 DPI (Fig. 2B) and the presence of persistent virus by plaque assay (Fig. 2C). These levels were similar to that seen in AAV-hACE2 $\mathrm{Rag}^{-/-}$infected mice (Fig. 1B). Notably, CD4 ${ }^{+} \mathrm{T}$ cell, but not $\mathrm{CD} 8^{+} \mathrm{T}$ cell, depletion significantly reduced the development of anti-SARSCoV-2 Spike S1 and RBD antibody titers, consistent with CD4 ${ }^{+}$ helper function in antibody development against SARS-CoV2 Spike and RBD (Fig S1 A-D). Somewhat surprisingly, depletion of $\mathrm{CD} 8^{+} \mathrm{T}$ cells in addition to $\mathrm{CD}^{+} \mathrm{T}$ cells further reduced antibody against Spike and RBD. These results also indicate that while adaptive immunity is required, either humoral or cellular adaptive immunity on its own is sufficient for viral clearance during a primary infection.

$T$ cells are required for $S A R S-C o V-2$ clearance in $B$ cell deficient mice

Next, we infected AAV-hACE2 $\mu \mathrm{MT}$ mice that had been treated with $\alpha \mathrm{CD} 4, \alpha \mathrm{CD} 8$ or $\alpha \mathrm{CD} 4 / \alpha \mathrm{CD} 8$ depleting antibodies to assess the $\mathrm{T}$ cell component required for viral clearance in the absence of humoral responses. We found that AAVhACE2 $\mu \mathrm{MT}$ mice treated with CD8-depleting antibody maintained significantly higher levels of viral RNA (92x) than the PBS controls as well as persistent live virus by plaque assay (Fig. 2D, E). On the other hand, AAV-hACE2 $\mu \mathrm{MT}$ mice treated with $\alpha$ CD4 antibody alone sustained only a small yet significant $(3.7 \mathrm{x})$ increase in viral RNA relative to control at 14DPI (Fig. 2D, E). Depletion of both CD4 and CD8 T cells lead to significantly higher levels of viral RNA (320x) compared to
PBS treated at 14 DPI (Fig. 2D). Interestingly, similar to the difference between $\alpha \mathrm{CD} 4$ treated, and PBS treated mice, there was a small increase in viral RNA in $\alpha \mathrm{CD} 4 / \alpha \mathrm{CD} 8$ treated $\mu \mathrm{MT}$ mice relative to $\alpha \mathrm{CD} 8$ treated mice $(3.5 \mathrm{x})$ as well as increase in persistent live virus (Fig. 2D, E), suggesting a small role for $\mathrm{CD}^{+} \mathrm{T}$ cells in the cellular immunity component of viral clearance in the absence of its effect on antibody development. Taken together, these data indicate that CD8 ${ }^{+}$ $\mathrm{T}$ cells are sufficient for viral clearance in the absence of humoral immunity, and that the major function of $\mathrm{CD} 4{ }^{+} \mathrm{T}$ cells in clearance of acute SARS-CoV-2 is in instructing humoral immunity, with a more minor role in assisting cellular immunity during primary infection.

\section{Transferred antibodies or $T$ cells provide protective} immunity in Rag $^{-/}$mice

Next, we investigated the sufficiency of SARS-CoV-2 specific $\mathrm{T}$ cell mediated versus antibody mediated immunity to protect against SARS-CoV-2 infection. To this end, we performed adoptive transfer of either $\mathrm{T}$ cells or sera from previously infected (convalescent) mice (Fig. 3A). We infected AAV-hACE2 WT mice with $1 \times 10^{6}$ PFU SARS-CoV-2. At 14 DPI, sera were harvested and total T-cells from mediastinal (draining) lymph nodes were isolated via magnetic negative selection. Recipient AAV-hACE2 Rag1 ${ }^{-/-}$mice were intravenously injected with either $2 \times 10^{6} \mathrm{~T}$ cells or with $200 \mu \mathrm{l}$ of pooled serum. At 24 hours post-transfer, mice were infected with $1 \times 10^{6}$ PFU SARS-CoV-2 intranasally. At 7 DPI, we found that while convalescent $\mathrm{T}$ cell transfer resulted in detectable reduction in viral RNA and titers in the lung, transfer of convalescent sera resulted in complete reduction in infectious viral load in the lung (Fig. 3B, C). These results indicated that in isolation, either cellular or humoral immunity can significantly reduce homologous SARS-CoV-2 infection, with antibodies being able to eliminate infectious virus from the lung.

Antibodies provide correlate of protection in mRNA vaccinated mice

To assess the potential for antibodies to provide a correlate of protection, we vaccinated K18 hACE2 mice (transgenic mice that express human ACE2 under the epithelial keratin 18 promoter), as they represent a lethal disease model of SARS-CoV-2 $(26,27)$, with the Pfizer-BioNTech BNT162b2 vaccine (Fig. $4 \mathrm{~A})(28)$. We performed single dose vaccination (ranging from $1.0 \mu \mathrm{g}$ to $0.03 \mu \mathrm{g}$ ) and found a dose-dependent SARS-CoV-2 specific antibody response (Fig. 4B) at 28 days post vaccination. Infection with $4 \times 10^{5} \mathrm{PFU}$ of homologous (WA1) strain SARS-CoV-2 at 30 days post vaccination also led to dose dependent protection defined by either weight loss (Fig. 4C) or survival (Fig. 4D). To assess the correlation between preinfection SAR-CoV-2 antibody levels (S1 IgG area under the curve (AUC)) and weight loss at 6 DPI (prior to any deaths) we performed Spearman's correlation and found a significant positive Spearman's correlation coefficient of 
0.7936 (Fig. 4E). Defining survival as protection, we performed a simple logistic regression model to identify the preinfection SAR-CoV-2 antibody level (S1 IgG AUC) required for $50 \%$ probability of survival, which we found to be 7.88 . Using this preinfection serum, we performed VSV-based pseudovirus neutralization assays and performed a similar analysis. We found a significant positive correlation between neutralization titer (IC50) and protection from weight loss, identifying 1:30 IC50 as the required neutralization titer for 50\% probability of survival (Fig. $4 \mathrm{G}, \mathrm{H}$ ).

Single dose mRNA vaccine elicits poor lung $\mathrm{CDB}^{+} \mathrm{T}_{\mathrm{RM}}$ response

To compare cellular and humoral responses to natural infection and to mRNA vaccine, mice were either infected with 500 PFU ( LD50) of SARS-CoV-2 WA1 strain or received single dose $1 \mu \mathrm{g}$ BNT162b2. At 14 days post immunization or infection, mice were assessed for anti-Spike S1 IgG and spike specific $\mathrm{CD}^{+} \mathrm{T}$ cells using S539-546 epitope MHC I tetramer staining from lung samples $(29,30)$. Using IV labeling, we identified that both groups developed similar levels of circulating $\left(\mathrm{IV}^{+}\right)$spike specific $\mathrm{CD}^{+} \mathrm{T}$ cells $\left(\mathrm{CD}^{+}{ }^{+}\right.$-etramer $\left.{ }^{+}\right)(\mathrm{Fig}$ S2A, B). Conversely, we found that only convalescent mice developed high levels of SARS-CoV-2 specific lung resident (IV) $\mathrm{CD}^{+} \mathrm{T}$ cells, while vaccinated mice did not (Fig S2A, B). Theses $\mathrm{IV}^{-} \mathrm{CD} 8^{+}$Tetramer $^{+} \mathrm{T}$ cells were enriched in tissue resident memory $\left(\mathrm{T}_{\mathrm{RM}}\right)$ markers $\left(\mathrm{CD} 9^{+} \mathrm{CD}{ }^{+}{ }^{+}\right)$(Fig S2C, D). We found that both groups developed similar serum levels of spike specific IgG (Fig S2E). We therefore hypothesized that lung $\mathrm{CD}^{+} \mathrm{T}_{\mathrm{RM}}$ memory cells may play a more important role in protection of convalescent mice than in vaccinated mice given their localization at the site of infection.

\section{Neutralizing antibodies drive protection from SARS-CoV-2 variants in convalescent and mRNA vac- cinated mice}

To assess this hypothesis and further understand the role of cellular and humoral memory in protection generated by both vaccination and natural infection, we performed variant viral challenge experiments with vaccinated and convalescent mice K18 mice in the setting of local and systemic CD8 ${ }^{+}$ $\mathrm{T}$ cell depletion. In these experiments, the vaccinated group received $1 \mu \mathrm{g}$ mRNA Pfizer-BioNTech COVID-19 vaccine twice, separated by 30 days, via intramuscular injection, and then were infected with SARS-CoV-2 at 3-5 weeks post boost. The convalescent group were infected with LD50 ( 500 PFU) of WA1 strain 1-3 months prior to reinfection (Fig. 5A). Three days prior to infection, serum samples were taken from vaccinated and convalescent mice and assessed for anti-SARSCoV-2 S1 antibody level by ELISA and neutralization capacity against WA1 and B.1.351 by VSV pseudovirus. Similar to what is seen in patient serum, we found that prime/boost vaccinated mice mounted higher antibody titer and higher neutralization levels against WA1 than convalescent mice (31) and found a reduction in neutralization titer against B.1.351 (32) (33) (Fig. 5B, C).

Mice from the convalescent and vaccinated groups were then treated with CD8-depleting antibody or with PBS via systemic (intraperitoneal) administration at $-3,-1$, and +2 days relative to infection and via local (intranasal) administration -1 day prior to infection (Fig. 5A). Depletion of both parenchymal and systemic $\mathrm{CD}^{+} \mathrm{T}$ cells was confirmed by IV labeling and flowcytometry (Fig S3A-C) of convalescent mice. Mice were infected with $4 \times 10^{5}$ PFU of either homologous strain (WA1) or a variant of concern (B.1.351) known to evade antibody neutralization from both convalescent and vaccinated people (16-19). We found that all the mice were resistant to disease, showing no physical signs of disease or weight loss (Fig. 5D, E). By contrast, naïve mice infected with either WA1 or B.1.351 developed significant weight loss and visible signs of sickness, including reduced activity and responsiveness, succumbing to infection by 4 DPI (Fig. 5D, E). Additionally, these two viruses seemed to replicate with similar efficacy in naïve mice as indicated by equal RNA levels at 2 DPI (Fig. 5F) and 4 DPI (Fig S4A), and equal viral titer at 2 DPI (Fig. 5G).

At 2 DPI PBS treated vaccinated mice challenged with homologous WA1 resulted in 4 orders of magnitude reduction in viral RNA relative to naïve, while vaccinated mice challenged with B.1.351 only resulted in a 2 orders of magnitude reduction relative to naïve (Fig. $5 \mathrm{~F}$ ). Similar results held at 7 DPI where 0/5 WA1 infected and 4/5 B.1.351 infected PBS treated animals had detectable viral RNA (Fig S4B). Convalescent mice at 2 DPI also sustained a 4 orders of magnitude reduction in viral RNA relative to naïve when infected with WA1 and sustained a 3 orders of magnitude reduction in viral RNA when infected with B.1.351 relative to naïve (Fig. 5F). Similarly, there was a $\sim 0.5 \log$ reduction in WA1 viral RNA relative to B.1.351 at 7 DPI in the PBS treated convalescent mice (Fig S4C). Interestingly, we found no change in viral RNA in vaccinated or convalescent mice depleted of $\mathrm{CD}^{+} \mathrm{T}$ cells relative to PBS treatment in the setting of WA1 infection, and we found only small (not significant) increases in viral RNA in the setting of immune evasive B.1.351 infection at 2 DPI (Fig. 5F) or 7 DPI (Fig. S4B, C).

Consistent with weight loss and mortality results, neither vaccinated nor convalescent mice had detectable viral titer at 2 DPI by either homologous WA1 or B.1.351 challenge irrespective of $\mathrm{CD}^{+} \mathrm{T}$ cell depletion (Fig. 5G). However, these data do show that mice infected with B.1.351 either in the vaccinated or the convalescent group had significantly higher levels of viral RNA than mice infected with WA1. Additionally, the mice treated with $\alpha \mathrm{CD} 8$ sustained only modestly higher levels of viral RNA compared to PBS treated mice infected by the same virus. We found this to be the case in either vaccinated or convalescent mice, suggesting that 
memory T cells, either circulating or resident within the lung, do not play a significant role in protection in the setting of overwhelming neutralizing antibody capacity. Thus, our results indicate that both vaccination and prior infection provide significant protection against infection and complete protection against disease by B.1.351 VOC, likely due to sufficient antibodies.

\section{DISCUSSION}

Here we describe our use of mouse models of SARS-CoV2 infection to identify components of adaptive immunity responsible for both viral clearance during primary infection and protection from reinfection. We found that, similar to COVID-19 patients (23) (24) (34) (35), mice require an adaptive immune response to clear SARS-CoV-2. This indicates that in this model, innate immunity is insufficient to clear infection, which may be due to antagonism of interferon pathway by the virus (36). We found that either cellular or humoral arms of the adaptive immune system are sufficient to promote viral clearance, as either B cell deficient mice or mice treated with $\alpha \mathrm{CD} 8$ or $\alpha \mathrm{CD} 4$ antibodies alone can clear SARS-CoV-2 infection, albeit slower than in the setting of a fully competent adaptive immune system. However, depletion of both $\mathrm{CD}^{+}$and $\mathrm{CD}^{+} \mathrm{T}$ cells in WT mice or depletion of $\mathrm{CD}^{+} \mathrm{T}$ cells in $\mu \mathrm{MT}$ mice led to the inability to clear the virus during primary infection. We also found that the major contribution of $\mathrm{CD}^{+} \mathrm{T}$ cells to viral clearance during acute infection is likely the promotion of antibody production, as treatment of $\mu \mathrm{MT}$ mice, devoid of antibodies, with $\alpha \mathrm{CD} 4$ only led to a small increase in viral RNA. These results indicate that $\mathrm{CD}^{+}{ }^{+}$cytotoxic $\mathrm{T}$ cells do not play a major role in viral clearance during primary infection. Consistent with these results, antigen specific CD4 $4^{+} \mathrm{T}$ cell profiling of acute and convalescent COVID-19 patients has shown that circulating $\mathrm{T}$ follicular helper cells are associated with reduced disease severity (37), indicating the importance of antibody promoting $\mathrm{CD}^{+} \mathrm{T}$ cells clearance of acute infection. COVID-19 patient studies have shown that antigen specific $\mathrm{CD}^{+} \mathrm{T}$ cells can be detected as early as 2-4 days from symptom onset, and their early detection was found to be associated with improved outcomes and viral clearance $(37,38)$. These data clearly show that both humoral and cellular adaptive immunity contribute to clearance of SARS-CoV-2 during primary infection, and are consistent with recent patient studies showing a correlation between clinical outcome and a robust coordinated adaptive response requiring $\mathrm{CD}^{+} \mathrm{T}$ cells, $\mathrm{CD} 8^{+} \mathrm{T}$ cells, and antibodies (37, 39).

Adaptive immune memory has been detected for as long as 8 months after primary infection with SARS-CoV-2 consisting of memory $\mathrm{CD}^{+}{ }^{+} \mathrm{T}$ cells, $\mathrm{CD}^{+} \mathrm{T}$ cells, $\mathrm{B}$ cells and antibodies $(1,4,40,41)$. Epidemiologic evidence also indicates that immune memory is sufficient to protect against reinfection in patients who have seroconverted, and mRNA-based vaccines have also show $>90 \%$ efficacy in preventing COVID19 in both phase III clinical trials and in real world settings $(3,13-15)$. As both vaccines and natural infection induce multiple types of immune memory and because reinfections in humans have been so rare, identifying the distinct components of adaptive immune memory that confer protection remain unknown. While protective immunity after primary infection or vaccine has been shown in multiple animal models, few have identified correlates of protection (5-12). Many of these studies have also shown that adoptive transfer of serum from convalescent or vaccinated animals or from humans confers protection. However, the role that $\mathrm{T}$ cells play in conferring protection either from vaccination or natural infection has received less attention than antibodies until recently, due to emerging immune evasive variants. To begin to assess the individual components of adaptive immunity that confer protection, McMahan et al. (6) recently showed that macaques treated with CD8-depleting antibody had higher RNA viral loads in nasal swab at 1 DPI than mock treated animals. However, this difference normalized by 2 DPI, and no difference at any time post infection was noted in BAL, suggesting that CD8 $\mathrm{T}_{\mathrm{RM}}$ may only confer added protection in the upper respiratory tract of macaques. In mouse models, nucleocapsid $(\mathrm{N})$ based vaccines, which rely mostly on $\mathrm{T}$ cellbased protection, have shown differing results. Matchett et al. found that IV administration of Adenovirus 5 vector expressing $\mathrm{N}$ protein conferred protection (42), while Dinnon et al. showed no protection via foot pad injection of Venezuelan equine encephalitis virus replicon particle expressing $\mathrm{N}$ (43). While it is possible that the different vectors led to differential protection, it seems more likely that IV administration led to antigen specific $\mathrm{T}_{\mathrm{RM}}$ in the lungs, which may not have developed in the setting of footpad inoculation.

To expand upon these studies in identifying the individual roles of humoral and cellular immunity in protection, we performed adoptive transfer experiments in mice deficient in adaptive immunity $\left(\mathrm{RAG}^{-/-}\right)$and found that both $\mathrm{T}$ cells and convalescent serum from previously infected animals could reduce viral load. However, only serum was able to achieve viral clearance. To identify the level of antibodies required for protection we performed variable mRNA vaccine dosing and showed that dose dependent protection highly correlated with antibody levels and identified IC50 of 1:30 as providing $50 \%$ protection in $\mathrm{K} 18$ mice. Consistent with McMahan et al. (6), we showed that memory $\mathrm{CD}^{+} \mathrm{T}$ cells, either $\mathrm{T}_{\mathrm{RM}}$ or circulating memory cells, are not required to confer significant protective immunity in the lower respiratory tract in either convalescent or vaccinated animals. In these experiments, it is likely that the $\mathrm{CD}^{+} \mathrm{T}$ cell contribution is limited in the setting of overwhelming humoral response, given that prime/boost vaccine or convalescent mice maintained IC50 $>$ 1:1000 to B.1.351. These data support antibody responses as 
the key determinant of protection from mRNA vaccines or natural infection against SARS-CoV-2 reinfection by current circulating VOCs. One caveat to this conclusion is that we did not specifically address whether $\mathrm{T}_{\mathrm{RM}}$ cell mediated immunity, in the absence of humoral responses is sufficient for protection as was shown by Matchett et al. (42). Additionally, we did not specifically address the role of $\mathrm{CD}_{4}^{+} \mathrm{T}$ cells in protective immunity, these have been shown to be important in SARS-CoV-1 protection in the absence of antibody mediated immunity (44).

SARS-CoV-2 variants that significantly evade humoral immunity have recently been identified. The variant which has consistently shown the strongest ability to evade humoral responses in in vitro neutralization assays is B.1.351 $(17,33,45)$. We found that while there was some loss of protection against infection in either vaccinated or convalescent mice, humoral immunity was sufficient to completely protect from disease in mice infected by B.1.351. These data build upon a recent case control study that reported increased rates of vaccine breakthrough with B.1.351 in fully vaccinated subjects, though most cases were asymptomatic (16). However, the degree to which mRNA vaccinated people are susceptible to clinical disease by B.1.351 remains unclear. While we identified antibodies as a correlate of protection and a IC50 titer of 1:30 as proving $50 \%$ protection in K18 mice, extreme caution should be used with application of this number beyond this model. Further studies that build on the work of Khoury et al. (46) will be required to assess the neutralizing antibody titers required to prevent COVID-19 in humans.

In conclusion, we provide insights into both the immunologic determinants of viral clearance and protection. While $\mathrm{T}$ cells were important in the clearance of primary infection, they were not required for protection against reinfection or vaccine-mediated protection, likely due to sufficient antibody-mediated immunity. These results are reassuring as they indicate that a robust humoral immune response is sufficient even in the setting of decreased neutralizing capacity. These results also have important public health and vaccine development implications, as they suggest that antibody mediated immunity may be a sufficient correlate of protection.

\section{MATERIALS AND METHODS \\ Study design}

The objective of this study was to identify the adaptive immune determinants of SARS-CoV-2 viral clearance and protection. To address the determinants of SARS-CoV-2 clearance, we chose to employ our recently developed mouse model of SARS-CoV-2 infection as it allowed us to utilize an array of genetic models combined with well-established cellular depletion techniques. To investigate the determinants of protection mediated by either prior infection or mRNA vaccine currently being used in humans, we utilized a commercially available human ACE2 transgenic mouse that has been well established as a model of SARS-CoV-2 lethality and combined this with cellular depletion techniques and infection by immune evasive SAR-CoV-2 variants.

\section{Safety}

All procedures were performed in a BSL-3 facility (for SARS-CoV-2-infected mice) with approval from the Yale Institutional Animal Care and Use Committee and Yale Environmental Health and Safety.

\section{Cell lines and viruses}

As reported in previous manuscripts (20), Vero E6 kidney epithelial cells were cultured in Dulbecco's Modified Eagle Medium (DMEM) supplemented with $1 \%$ sodium pyruvate (NEAA) and $5 \%$ fetal bovine serum (FBS) at $37^{\circ} \mathrm{C}$ and $5 \% \mathrm{CO} 2$. Huh7.5 and 293T cells were cultured in DMEM supplemented with $1 \%$ sodium pyruvate and $10 \%$ fetal bovine serum (FBS) at $37^{\circ} \mathrm{C}$ and $5 \% \mathrm{CO} 2$. The cell line was obtained from the ATCC and has been tested negative for contamination with mycoplasma. SARS-CoV-2 isolate hCOV-19/USA-WA1/2020 (NR-52281) and SARS-CoV-2 Isolate hCoV-19/South Africa/KRISP-K005325/2020 (NR-54009) was obtained from BEI Resources and was amplified in either VeroE6 (ATCC CRL-1586) cells or VeroE6 cells overexpressing hACE2 and TMPRSS2 (kindly provided by Barney Graham NIH-VRC). Cells were infected at a MOI 0.01 for two-three days to generate a working stock and after incubation the supernatant was clarified by centrifugation $(500 \mathrm{~g} \times 5 \mathrm{~min})$ and filtered through a 0.45 -micron filter. To concentrate virus, filtered supernatants were applied to Amicon Ultra- 15 centrifugal filter (Ultracel 100k) and spun at $2000 \mathrm{rpm}$ for $15 \mathrm{~min}$. The supernatant was then aliquoted for storage at $-80^{\circ} \mathrm{C}$. Viral titers were measured by standard plaque assay using Vero E6 cells described below.

\section{Mice}

Six to twelve-week-old mixed sex C57Bl/6J (WT), B6.129S7-Rag1tm1Mom/J (Rag1 $\left.{ }^{-/}\right)$, B6.129S2-Ighmtm1Cgn/J $(\mu \mathrm{MT})$, and B6.Cg-Tg(K18-ACE2)2Prlmn/J (K18) were purchased from Jackson laboratories, and were subsequently bred and housed at Yale University. All procedures used in this study (sex-matched, age-matched) complied with federal guidelines and the institutional policies of the Yale School of Medicine Animal Care and Use Committee.

\section{AAVinfection}

As previously described (20), adeno-associated virus 9 encoding hACE2 was purchased from Vector biolabs (AAVCMV-hACE2). Animals were anaesthetized using a mixture of ketamine (50 $\mathrm{mg} \mathrm{kg}-1$ ) and xylazine (5 mg kg-1), injected intraperitoneally. The rostral neck was shaved and disinfected. A $5 \mathrm{~mm}$ incision was made and the salivary glands were retracted, and trachea was visualized. Using a $32 \mathrm{~g}$ insulin syringe a $50 \mu \mathrm{L}$ bolus injection of $10^{11}$ genomic copies of AAVCMV-hACE2 was injected into the trachea. The incision was closed with 4-0 Vicryl suture. Following intramuscular 
administration of analgesic (Meloxicam and buprenorphine, $1 \mathrm{mg} \mathrm{kg}-1$ ), animals were placed in a heated cage until full recovery. Mice were used for SARS-CoV-2 infection at 14-21 days post AAV administration.

\section{SARS-CoV-2 infection}

Mice were anesthetized using $30 \% \mathrm{v} / \mathrm{v}$ Isoflurane diluted in propylene glycol. Using a pipette, $50 \mu \mathrm{L}$ of SARS-CoV-2 was delivered intranasally.

\section{$\mathrm{CD4}^{+}$and $\mathrm{CDs}^{+} \mathrm{T}$ cell depletion}

Indicated mice were injected intraperitoneally with PBS or 200ug in 200ul diluted in PBS of either anti-mouse CD4 (BioXcell InVivoMab Clone GK 1.5), anti-mouse CD8 (BioXcell InVivoMab Clone 2.43) or both at indicated time points. For local pulmonary CD8 depletion,100ug of anti-mouse CD8 $\mathrm{Ab}$ was given intranasally in 50ul of volume diluted in PBS.

\section{Adoptive transfer experiments}

WT AAV-hACE2 mice were infected as indicated above. At 14 DPI animals were euthanized and blood and mediastinal lymph nodes collected. Blood was allowed to coagulate at room temperature for 30minutes and then was centrifuged at $3900 \mathrm{rpm}$ for $20 \mathrm{~min}$ at 4c. Serum was collected, and anesthetized mice ( $30 \% \mathrm{v} / \mathrm{v}$ Isoflurane diluted in propylene glycol) were injected with $200 \mathrm{ul}$ serum with a $32 \mathrm{~g} 8 \mathrm{~mm}$ syringe via retro orbital route. Mediastinal lymph nodes were mechanically dissociated in 500ul of cold PBS and passed through a 40um filter. Cells were counted in duplicate on the Countess II (Invitrogen) and total T-cell isolation was performed via negative selection using the EasySepTM mouse T cell isolation kit (Stemcell). Isolated cells were counted and 2x106 total $\mathrm{T}$ cells were diluted in 200ul PBS and retro-orbitally injected into anesthetized mice.

\section{Vaccination}

Used vials of Pfizer/BioNTec BNT162b2 mRNA vaccine were acquired from Yale Health pharmacy within 6 hours of opening. No vaccines were diverted for the purposes of this study and the vaccine residual volumes described in this study were obtained only after usage by Yale Health and prior to discarding. All vials contained residual vaccine volumes (less than 1 full dose per vial, diluted to $100 \mathrm{ug} / \mathrm{ml}$ per manufacturer's instructions) and remaining liquid was removed with spinal syringe and pooled. Vaccine was not stored or refrozen prior to use, but was directedly used. Mice were anaesthetized using a mixture of ketamine $(50 \mathrm{mg} \mathrm{kg}-1)$ and xylazine (5 $\mathrm{mg} \mathrm{kg}-1)$, and $10 \mathrm{ul}(\mathrm{lmg})$ of undiluted vaccine was injected into left quadriceps muscle with a $32 \mathrm{~g}$ syringe.

\section{Viral RNA analysis}

At indicated time points mice were euthanized in $100 \%$ Isoflurane. $~ 50 \%$ of total lung was placed in a bead homogenizer tube with $1 \mathrm{ml}$ of $\mathrm{PBS}+2 \% \mathrm{FBS}+2 \%$ antibiotic/antimycotic (Gibco). After homogenization 250ul of this mixture was placed in 750ul Trizol LS (Invitrogen), and RNA was extracted with RNeasy mini kit (Qiagen) per manufacturer protocol. To quantify SARS-CoV-2 RNA levels, we used the Luna Universal Probe Onestep RT-qPCR kit (New England Biolabs) with 1 ug of RNA, using the US CDC real-time RT-PCR primer/probe sets for 2019-nCoV_N1.

\section{Viral titer}

Lung homogenates were cleared of debris by centrifugation (3900rpm for $10 \mathrm{~min}$ ). Infectious titers of SARS-CoV-2 were determined by plaque assay in Vero E6 cells in DMEM supplemented NaHCO3, 2\% FBS 0.6\% Avicel RC-581. Plaques were resolved at $48 \mathrm{hrs}$ post infection by fixing in $10 \%$ Neutral buffered formalin for 1 hour followed by staining for 1 hour in $0.5 \%$ crystal violet in $20 \%$ ethanol for $30 \mathrm{~min}$. Plates were rinsed in water to visualize plaques.

\section{SARS-CoV-2 specific-antibody measurements}

ELISAs were performed as previously described $(20,47)$ and reproduced here for convenience. Briefly, Triton X-100 and RNase A were added to serum samples at final concentrations of $0.5 \%$ and $0.5 \mathrm{mg} / \mathrm{ml}$ respectively and incubated at room temperature (RT) for $30 \mathrm{~min}$ before use to reduce risk from any potential virus in serum. 96-well MaxiSorp plates (Thermo Scientific \#442404) were coated with $50 \mu \mathrm{l} /$ well of recombinant SARS CoV-2 S1 protein (ACROBiosystems S1NC52H3) and RBD (ACROBiosystems SPD-C52H3) at a concentration of $2 \mu \mathrm{g} / \mathrm{ml}$ in PBS and were incubated overnight at $4^{\circ} \mathrm{C}$. The coating buffer was removed, and plates were incubated for $1 \mathrm{~h}$ at RT with $250 \mu \mathrm{l}$ of blocking solution (PBS with $0.1 \%$ Tween-20, $3 \%$ milk powder). Serum was diluted in dilution solution (PBS with $0.1 \%$ Tween-20, $1 \%$ milk powder) and $100 \mu \mathrm{l}$ of diluted serum was added for two hours at RT. Plates were washed three times with PBS-T (PBS with $0.1 \%$ Tween20) and $50 \mu$ l of HRP anti-mouse IgG (Cell Signaling Technology $\# 7076,1: 3,000$ ) diluted in dilution solution added to each well. After 1 hour of incubation at RT, plates were washed three times with PBS-T. Plates were developed with $100 \mu \mathrm{l}$ of TMB Substrate Reagent Set (BD Biosciences \#555214) and the reaction was stopped after $15 \mathrm{~min}$ by the addition of $2 \mathrm{~N}$ sulfuric acid. Plates were then read at a wavelength of $450 \mathrm{~nm}$ and $570 \mathrm{~nm}$.

\section{Pseudovirus production}

Vesicular stomatitis virus (VSV)-based pseudotyped viruses were produced as previously described (48-50). Vector pCAGGS containing the SARS-CoV-2 Wuhan-Hu-1 spike glycoprotein gene was produced under HHSN272201400008C and obtained through BEI Resources (NR-52310). The sequence of the Wuhan-Hu-1 isolate spike glycoprotein is identical to that of the USA-WA1/2020 isolate. The spike sequence of the B.1.351 variant of concern was generated by introducing the following mutations: L18F, D80A, D215G, R246I, K417N, E484K, N501Y, and A701V. 293T cells were transfected with either spike plasmid, followed by inoculation with replication deficient VSV expressing Renilla luciferase for 1 hour at $37^{\circ} \mathrm{C}(9)$. The virus inoculum was then removed, and 
cells were washed three times with warmed PBS. Supernatant containing pseudovirus was collected 24 and 48 hours post inoculation, clarified by centrifugation, concentrated with Amicon Ultra Centrifugal Filter Units (100 kDa), and stored in aliquots at $-80^{\circ} \mathrm{C}$. Pseudoviruses were titrated in Huh7.5 cells to achieve a relative light unit (RLU) signal of $\sim 600$ times the cell-only control background.

\section{Pseudovimus neutralization assay}

$3 \times 10^{4}$ Huh7.5 cells were plated in each well of a 96-well plate the day before infection. On the day of infection sera for neutralization assay were heat-inactivated for $30 \mathrm{~min}$ at $56^{\circ} \mathrm{C}$. Sera were tested at a starting dilution of 1:10 (Fig. 4) and 1:50 (Fig. 5) for USA-WA1/2020 pseudovirus and 1:40 for B.1.351 pseudovirus, with 8 or 12 two-fold serial dilutions. Serial dilutions of sera were incubated with pseudovirus for 1 hour at $37^{\circ} \mathrm{C}$. Growth media was then aspirated from the cells and replaced with $100 \mu \mathrm{l}$ of serum/virus mixture. Luciferase activity was measured at 24 hours post infection using the Renilla-Glo Luciferase Assay System (Promega). Each well of cells was lysed with $20 \mu \mathrm{l}$ Passive Lysis Buffer, freeze thawed $1 \mathrm{x}$, and then mixed with $20 \mu \mathrm{l}$ Luciferase Assay reagent. Luminescence was measured on a microplate reader (SpectraMax i3, Molecular Devices). Half maximal inhibitory concentration (IC50) was calculated as using Prism 9 (GraphPad Software) non-linear regression.

\section{Intravascular labeling, cell isolation, and flow cy-} tometry

To discriminate intravascular from extravascular cells, mice were anesthetized with $30 \%$ Isoflurane and injected i.v. with APC/Fire 750 CD45 Ab (30-F11, AB_2572116 (BioLegend, \#103154) and after 3 min recovery, mice were euthanized. Tissues were harvested and analyzed as previously described (20). In short, lungs were minced with scissors and incubated in a digestion cocktail containing $1 \mathrm{mg} / \mathrm{ml}$ collagenase A (Roche) and $30 \mu \mathrm{g} / \mathrm{ml}$ DNase I (Sigma-Aldrich) in RPMI at $37^{\circ} \mathrm{C}$ for $45 \mathrm{~min}$. Tissue was then filtered through a $70-\mu \mathrm{m}$ filter. Cells were treated with ammonium-chloride-potassium buffer and resuspended in PBS with $1 \%$ BSA. Single cell suspensions were incubated at $4{ }^{\circ} \mathrm{C}$ with $\mathrm{Fc}$ block and Aqua cell viability dye for $20 \mathrm{~min}$. After washing with PBS, cells were stained with (anti-CD103(BV42, 2E7, AB_2562901, BioLegend \#121422)), (anti-CD3(BV605, 17A2, AB_2562039, BioLegend \#100237)), (anti-CD44(BV711, IM7, AB_2564214, BioLegend \#103057)), (anti-CD62L(FITC, MEL-14，AB_313093, BioLegend \# 104406)), (anti-CD8a(PerCP/Cy5.5, 16-10A1, AB_2566491, BioLegend \#305232)), (anti-CD69(PE/Cy7, H1.2F3, AB_493564, BioLegend \#104512)), (antiCD183(CXCR3)(APC，CXCR3-173，AB_1088993，BioLegend \#126512)), (anti-CD4(AF700, GK 1.5, AB_493699, BioLegend \#100430)), and (PE-SARS-CoV-2 S 539-546 MHC class I tetramer $(\mathrm{H}-2 \mathrm{~K}(\mathrm{~b}))$ for $30 \mathrm{~min}$ at $4^{\circ} \mathrm{C}$. After washing with PBS, cells were fixed using $4 \%$ paraformaldehyde. Cell population data were acquired on an Attune NxT Flow Cytometer and analyzed using FlowJo Software (10.5.3; Tree Star). See (Fig. S5) for gating strategy.

\section{Statistical analysis}

Prism 9 (GraphPad) was used for all analysis. Statistical significance was determined using one-way ANOVA or twoway Anova with Tukey's multiple comparison test or Student's two-tailed, unpaired $t$ test where indicated in the figure ledged. $\mathrm{P}<0.05$ was considered statistically significant.

\section{Graphics}

Created with BioRender.com

\section{SUPPLEMENTARY MATERIALS}

www.science.org/doi/10.1126/sciimmunol.abl4509

Figure S1. SARS-CoV-2 antibody production in $\mathrm{CD}^{+}$and $\mathrm{CD}^{+}$depleted mice Figure S2. $\mathrm{CD}^{+} \mathrm{T}_{\mathrm{RM}}$ develop in infected mice, not $\mathrm{mRNA}$ vaccinated mice

Figure S3. Depletion of $\mathrm{CD}^{+} \mathrm{T}_{\mathrm{RM}}$ cells in convalescent mice

Figure S4. Naïve, vaccinated, and convalescent mice infected with WA1 or B.1.351 Figure S5. Assessment of CD8 ${ }^{+} \mathrm{T}_{\mathrm{RM}}$ cells

Table S1. Raw data file (excel)

\section{REFERENCES AND NOTES}

1. J. M. Dan, J. Mateus, Y. Kato, K. M. Hastie, E. D. Yu, C. E. Faliti, A. Grifoni, S. I. Ramirez, S. Haupt, A. Frazier, C. Nakao, V. Rayaprolu, S. A. Rawlings, B. Peters, F. Krammer, V. Simon, E. O. Saphire, D. M. Smith, D. Weiskopf, A. Sette, S. Crotty, Immunological memory to SARS-CoV-2 assessed for up to 8 months after infection. Science 371, eabf4063 (2021). doi:10.1126/science.abf4063 Medline

2. A. Grifoni, D. Weiskopf, S. I. Ramirez, J. Mateus, J. M. Dan, C. R. Moderbacher, S. A. Rawlings, A. Sutherland, L. Premkumar, R. S. Jadi, D. Marrama, A. M. de Silva, A. Frazier, A. F. Carlin, J. A. Greenbaum, B. Peters, F. Krammer, D. M. Smith, S. Crotty, A. Sette, Targets of T Cell Responses to SARS-CoV-2 Coronavirus in Humans with COVID-19 Disease and Unexposed Individuals. Cell 181, 1489 1501.e15 (2020). doi:10.1016/i.cell.2020.05.015 Medline

3. L. R. Baden, H. M. El Sahly, B. Essink, K. Kotloff, S. Frey, R. Novak, D. Diemert, S. A. Spector, N. Rouphael, C. B. Creech, J. McGettigan, S. Khetan, N. Segall, J. Solis, A. Brosz, C. Fierro, H. Schwartz, K. Neuzil, L. Corey, P. Gilbert, H. Janes, D. Follmann, M. Marovich, J. Mascola, L. Polakowski, J. Ledgerwood, B. S. Graham, H. Bennett, R. Pajon, C. Knightly, B. Leav, W. Deng, H. Zhou, S. Han, M. Ivarsson, J. Miller, T. Zaks; COVE Study Group, Efficacy and Safety of the mRNA-1273 SARS-CoV-2 Vaccine. N. Engl. J. Med. 384, 403-416 (2021). doi:10.1056/NEJMoa2035389 Medline

4. L. B. Rodda, J. Netland, L. Shehata, K. B. Pruner, P. A. Morawski, C. D. Thouvenel, K K. Takehara, J. Eggenberger, E. A. Hemann, H. R. Waterman, M. L. Fahning, Y. Chen, M. Hale, J. Rathe, C. Stokes, S. Wrenn, B. Fiala, L. Carter, J. A. Hamerman, N. P. King, M. Gale Jr., D. J. Campbell, D. J. Rawlings, M. Pepper, Functional SARSCoV-2-Specific Immune Memory Persists after Mild COVID-19. Cell 184, 169183.e17 (2021). doi:10.1016/i.cell.2020.11.029 Medline

5. K. S. Corbett, B. Flynn, K. E. Foulds, J. R. Francica, S. Boyoglu-Barnum, A. P. Werner, B. Flach, S. O'Connell, K. W. Bock, M. Minai, B. M. Nagata, H. Andersen, D. R. Martinez, A. T. Noe, N. Douek, M. M. Donaldson, N. N. Nji, G. S. Alvarado, D. K. Edwards, D. R. Flebbe, E. Lamb, N. A. Doria-Rose, B. C. Lin, M. K. Louder, S. O'Dell, S. D. Schmidt, E. Phung, L. A. Chang, C. Yap, J. M. Todd, L. Pessaint, A. Van Ry, S. Browne, J. Greenhouse, T. Putman-Taylor, A. Strasbaugh, T. A. Campbell, A. Cook, A. Dodson, K. Steingrebe, W. Shi, Y. Zhang, O. M. Abiona, L. Wang, A. Pegu, E. S. Yang, K. Leung, T. Zhou, I. T. Teng, A. Widge, I. Gordon, L. Novik, R. A. Gillespie, R. J. Loomis, J. I. Moliva, G. Stewart-Jones, S. Himansu, W. P. Kong, M. C. Nason, K. M. Morabito, T. J. Ruckwardt, J. E. Ledgerwood, M. R. Gaudinski, P. D. Kwong, J. R. Mascola, A. Carfi, M. G. Lewis, R. S. Baric, A. McDermott, I. N. Moore, N. J. Sullivan, M. Roederer, R. A. Seder, B. S. Graham, Evaluation of the mRNA-1273 Vaccine against SARS-CoV-2 in Nonhuman Primates. N. Engl. J. Med. 383, 1544-1555 (2020). doi:10.1056/NEJMoa2024671 Medline

6. K. McMahan, J. Yu, N. B. Mercado, C. Loos, L. H. Tostanoski, A. Chandrashekar, J. Liu, L. Peter, C. Atyeo, A. Zhu, E. A. Bondzie, G. Dagotto, M. S. Gebre, C. Jacob- 
Dolan, Z. Li, F. Nampanya, S. Patel, L. Pessaint, A. Van Ry, K. Blade, J. YalleyOgunro, M. Cabus, R. Brown, A. Cook, E. Teow, H. Andersen, M. G. Lewis, D. A. Lauffenburger, G. Alter, D. H. Barouch, Correlates of protection against SARSCoV-2 in rhesus macaques. Nature 590, 630-634 (2021). doi:10.1038/s41586020-03041-6 Medline

7. N. B. Mercado, R. Zahn, F. Wegmann, C. Loos, A. Chandrashekar, J. Yu, J. Liu, L. Peter, K. McMahan, L. H. Tostanoski, X. He, D. R. Martinez, L. Rutten, R. Bos, D. van Manen, J. Vellinga, J. Custers, J. P. Langedijk, T. Kwaks, M. J. G. Bakkers, D. Zuijdgeest, S. K. Rosendahl Huber, C. Atyeo, S. Fischinger, J. S. Burke, J. Feldman, B. M. Hauser, T. M. Caradonna, E. A. Bondzie, G. Dagotto, M. S. Gebre, E. Hoffman, C. Jacob-Dolan, M. Kirilova, Z. Li, Z. Lin, S. H. Mahrokhian, L. F. Maxfield, F. Nampanya, R. Nityanandam, J. P. Nkolola, S. Patel, J. D. Ventura, K. Verrington, H. Wan, L. Pessaint, A. Van Ry, K. Blade, A. Strasbaugh, M. Cabus, R. Brown, A. Cook, S. Zouantchangadou, E. Teow, H. Andersen, M. G. Lewis, Y. Cai, B. Chen, A. G. Schmidt, R. K. Reeves, R. S. Baric, D. A. Lauffenburger, G. Alter, P. Stoffels, M. Mammen, J. Van Hoof, H. Schuitemaker, D. H. Barouch, Single-shot Ad26 vaccine protects against SARS-CoV-2 in rhesus macaques. Nature 586, 583-588 (2020). doi:10.1038/s41586-020-2607-z Medline

8. N. van Doremalen, T. Lambe, A. Spencer, S. Belij-Rammerstorfer, J. N. Purushotham, J. R. Port, V. A. Avanzato, T. Bushmaker, A. Flaxman, M. Ulaszewska, F. Feldmann, E. R. Allen, H. Sharpe, J. Schulz, M. Holbrook, A. Okumura, K. Meade-White, L. Pérez-Pérez, N. J. Edwards, D. Wright, C. Bissett, C. Gilbride, B. N. Williamson, R. Rosenke, D. Long, A. Ishwarbhai, R. Kailath, L. Rose, S. Morris, C. Powers, J. Lovaglio, P. W. Hanley, D. Scott, G. Saturday, E. de Wit, S. C. Gilbert, V. J. Munster, ChAdOx1 nCoV-19 vaccine prevents SARS-CoV-2 pneumonia in rhesus macaques. Nature 586, 578-582 (2020). doi:10.1038/s41586-020-2608-y Medline

9. J. Yu, L. H. Tostanoski, L. Peter, N. B. Mercado, K. McMahan, S. H. Mahrokhian, J. P. Nkolola, J. Liu, Z. Li, A. Chandrashekar, D. R. Martinez, C. Loos, C. Atyeo, S. Fischinger, J. S. Burke, M. D. Slein, Y. Chen, A. Zuiani, F. J. N. Lelis, M. Travers, S. Habibi, L. Pessaint, A. Van Ry, K. Blade, R. Brown, A. Cook, B. Finneyfrock, A Dodson, E. Teow, J. Velasco, R. Zahn, F. Wegmann, E. A. Bondzie, G. Dagotto, M. S. Gebre, X. He, C. Jacob-Dolan, M. Kirilova, N. Kordana, Z. Lin, L. F. Maxfield, F. Nampanya, R. Nityanandam, J. D. Ventura, H. Wan, Y. Cai, B. Chen, A. G. Schmidt, D. R. Wesemann, R. S. Baric, G. Alter, H. Andersen, M. G. Lewis, D. H. Barouch, DNA vaccine protection against SARS-CoV-2 in rhesus macaques. Science 369 , 806-811 (2020). doi:10.1126/science.abc6284 Medline

10. K. S. Corbett, D. K. Edwards, S. R. Leist, O. M. Abiona, S. Boyoglu-Barnum, R. A. Gillespie, S. Himansu, A. Schäfer, C. T. Ziwawo, A. T. DiPiazza, K. H. Dinnon, S. M. Elbashir, C. A. Shaw, A. Woods, E. J. Fritch, D. R. Martinez, K. W. Bock, M. Minai, B. M. Nagata, G. B. Hutchinson, K. Wu, C. Henry, K. Bahl, D. Garcia-Dominguez, L. Ma, I. Renzi, W. P. Kong, S. D. Schmidt, L. Wang, Y. Zhang, E. Phung, L. A. Chang, R. J. Loomis, N. E. Altaras, E. Narayanan, M. Metkar, V. Presnyak, C. Liu, M. K. Louder, W. Shi, K. Leung, E. S. Yang, A. West, K. L. Gully, L. J. Stevens, N. Wang, D. Wrapp, N. A. Doria-Rose, G. Stewart-Jones, H. Bennett, G. S. Alvarado, M. C. Nason, T. J. Ruckwardt, J. S. McLellan, M. R. Denison, J. D. Chappell, I. N. Moore, K. M. Morabito, J. R. Mascola, R. S. Baric, A. Carfi, B. S. Graham, SARS-CoV-2 mRNA vaccine design enabled by prototype pathogen preparedness. Nature $\mathbf{5 8 6}$, 567-571 (2020). doi:10.1038/s41586-020-2622-0 Medline

11. J. Sun, Z. Zhuang, J. Zheng, K. Li, R. L. Wong, D. Liu, J. Huang, J. He, A. Zhu, J. Zhao, X. Li, Y. Xi, R. Chen, A. N. Alshukairi, Z. Chen, Z. Zhang, C. Chen, X. Huang, F. Li, X. Lai, D. Chen, L. Wen, J. Zhuo, Y. Zhang, Y. Wang, S. Huang, J. Dai, Y. Shi, K. Zheng, M. R. Leidinger, J. Chen, Y. Li, N. Zhong, D. K. Meyerholz, P. B. McCray Jr., S. Perlman, J. Zhao, Generation of a Broadly Useful Model for COVID-19 Pathogenesis, Vaccination, and Treatment. Cell 182, 734-743.e5 (2020). doi:10.1016/i.cell.2020.06.010 Medline

12. R. L. Brocato, S. A. Kwilas, R. K. Kim, X. Zeng, L. M. Principe, J. M. Smith, J. W. Hooper, Protective efficacy of a SARS-CoV-2 DNA vaccine in wild-type and immunosuppressed Syrian hamsters. npj. Vaccines (Basel) 6, 16 (2021). doi:10.1038/s41541-020-00279-z Medline

13. N. Dagan, N. Barda, E. Kepten, O. Miron, S. Perchik, M. A. Katz, M. A. Hernán, M. Lipsitch, B. Reis, R. D. Balicer, BNT162b2 mRNA Covid-19 Vaccine in a Nationwide Mass Vaccination Setting. N. Engl. J. Med. 384, 1412-1423 (2021). doi:10.1056/NEJMoa2101765 Medline

14. F. P. Polack, S. J. Thomas, N. Kitchin, J. Absalon, A. Gurtman, S. Lockhart, J. L.
Perez, G. Pérez Marc, E. D. Moreira, C. Zerbini, R. Bailey, K. A. Swanson, S. Roychoudhury, K. Koury, P. Li, W. V. Kalina, D. Cooper, R. W. Frenck Jr., L. L. Hammitt, Ö. Türeci, H. Nell, A. Schaefer, S. Ünal, D. B. Tresnan, S. Mather, P. R. Dormitzer, U. Şahin, K. U. Jansen, W. C. Gruber; C4591001 Clinical Trial Group, Safety and Efficacy of the BNT162b2 mRNA Covid-19 Vaccine. N. Engl. J. Med. 383, 2603-2615 (2020). doi:10.1056/NEJMoa2034577 Medline

15. S. F. Lumley, D. O'Donnell, N. E. Stoesser, P. C. Matthews, A. Howarth, S. B. Hatch, B. D. Marsden, S. Cox, T. James, F. Warren, L. J. Peck, T. G. Ritter, Z. de Toledo, L. Warren, D. Axten, R. J. Cornall, E. Y. Jones, D. I. Stuart, G. Screaton, D. Ebner, S. Hoosdally, M. Chand, D. W. Crook, A. M. O'Donnell, C. P. Conlon, K. B. Pouwels, A. S. Walker, T. E. A. Peto, S. Hopkins, T. M. Walker, K. Jeffery, D. W. Eyre; Oxford University Hospitals Staff Testing Group, Antibody Status and Incidence of SARSCoV-2 Infection in Health Care Workers. N. Engl. J. Med. 384, 533-540 (2021). doi:10.1056/NEJMoa2034545 Medline

16. T. Kustin, N. Harel, U. Finkel, S. Perchik, S. Harari, M. Tahor, I. Caspi, R. Levy, M. Leschinsky, S. K. Dror, G. Bergerzon, H. Gadban, F. Gadban, E. Eliassian, 0. Shimron, L. Saleh, H. Ben-Zvi, D. Amichay, A. Ben-Dor, D. Sagas, M. Strauss, Y. S. Avni, A. Huppert, E. Kepten, R. D. Balicer, D. Nezer, S. Ben-Shachar, A. Stern, Evidence for increased breakthrough rates of SARS-CoV-2 variants of concern in BNT162b2 mRNA vaccinated individuals. medRxiv, 2021.2004.2006.21254882 (2021).

17. W. F. Garcia-Beltran, E. C. Lam, K. St Denis, A. D. Nitido, Z. H. Garcia, B. M. Hauser, J. Feldman, M. N. Pavlovic, D. J. Gregory, M. C. Poznansky, A. Sigal, A. G. Schmidt, A. J. lafrate, V. Naranbhai, A. B. Balazs, Multiple SARS-CoV-2 variants escape neutralization by vaccine-induced humoral immunity. Cell 184, 2372-2383.e9 (2021). doi:10.1016/i.cell.2021.03.013 Medline

18. K. R. W. Emary, T. Golubchik, P. K. Aley, C. V. Ariani, B. Angus, S. Bibi, B. Blane, D. Bonsall, P. Cicconi, S. Charlton, E. A. Clutterbuck, A. M. Collins, T. Cox, T. C. Darton, C. Dold, A. D. Douglas, C. J. A. Duncan, K. J. Ewer, A. L. Flaxman, S. N. Faust, D. M. Ferreira, S. Feng, A. Finn, P. M. Folegatti, M. Fuskova, E. Galiza, A. L. Goodman, C. M. Green, C. A. Green, M. Greenland, B. Hallis, P. T. Heath, J. Hay, H. C. Hill, D. Jenkin, S. Kerridge, R. Lazarus, V. Libri, P. J. Lillie, C. Ludden, N. G. Marchevsky, A. M. Minassian, A. C. McGregor, Y. F. Mujadidi, D. J. Phillips, E. Plested, K. M. Pollock, H. Robinson, A. Smith, R. Song, M. D. Snape, R. K. Sutherland, E. C. Thomson, M. Toshner, D. P. J. Turner, J. Vekemans, T. L. Villafana, C. J. Williams, A. V. S. Hill, T. Lambe, S. C. Gilbert, M. Voysey, M. N. Ramasamy, A. J. Pollard; COVID-19 Genomics UK consortium; AMPHEUS Project; Oxford COVID-19 Vaccine Trial Group, Efficacy of ChAdOx1 nCoV-19 (AZD1222) vaccine against SARS-CoV-2 variant of concern 202012/01 (B.1.1.7): An exploratory analysis of a randomised controlled trial. Lancet 397, 1351-1362 (2021). doi:10.1016/S0140-6736(21)00628-0 Medline

19. S. S. Abdool Karim, T. de Oliveira, New SARS-CoV-2 Variants - Clinical, Public Health, and Vaccine Implications. N. Engl. J. Med. 384, 1866-1868 (2021). doi:10.1056/NEJMc2100362 Medline

20. B. Israelow, E. Song, T. Mao, P. Lu, A. Meir, F. Liu, M. M. Alfajaro, J. Wei, H. Dong, R. J. Homer, A. Ring, C. B. Wilen, A. Iwasaki, Mouse model of SARS-CoV-2 reveals inflammatory role of type I interferon signaling. J. Exp. Med. 217, e20201241 (2020). doi:10.1084/jem.20201241 Medline

21. P. Mombaerts, J. lacomini, R. S. Johnson, K. Herrup, S. Tonegawa, V. E. Papaioannou, RAG-1-deficient mice have no mature B and T lymphocytes. Cell 68, 869-877 (1992). doi:10.1016/0092-8674(92)90030-G Medline

22. K. Guetl, F. Moazedi-Fuerst, K. Rosskopf, M. Brodmann, R. Krause, P. Eller, P. Wilhelmer, F. Eisner, N. Sareban, P. Schlenke, H. H. Kessler, I. Steinmetz, M. Redlberger-Fritz, K. Stiasny, M. Stradner, SARS-CoV-2 positive virus culture 7 weeks after onset of COVID-19 in an immunocompromised patient suffering from X chromosome-linked agammaglobulinemia. J. Infect. 82, 414-451 (2021). doi:10.1016/i.iinf.2020.10.025 Medline

23. B. Choi, M. C. Choudhary, J. Regan, J. A. Sparks, R. F. Padera, X. Qiu, I. H. Solomon, H. H. Kuo, J. Boucau, K. Bowman, U. D. Adhikari, M. L. Winkler, A. A. Mueller, T. Y. Hsu, M. Desjardins, L. R. Baden, B. T. Chan, B. D. Walker, M. Lichterfeld, M. Brigl, D. S. Kwon, S. Kanjilal, E. T. Richardson, A. H. Jonsson, G. Alter, A. K. Barczak, W. P. Hanage, X. G. Yu, G. D. Gaiha, M. S. Seaman, M. Cernadas, J. Z. Li, Persistence and Evolution of SARS-CoV-2 in an Immunocompromised Host. N. Engl. J. Med. 383, 2291-2293 (2020). doi:10.1056/NEJMc2031364 Medline

24. V. A. Avanzato, M. J. Matson, S. N. Seifert, R. Pryce, B. N. Williamson, S. L. Anzick, 
K. Barbian, S. D. Judson, E. R. Fischer, C. Martens, T. A. Bowden, E. de Wit, F. X. Riedo, V. J. Munster, Case Study: Prolonged Infectious SARS-CoV-2 Shedding from an Asymptomatic Immunocompromised Individual with Cancer. Cell 183, 1901-1912.e9 (2020). doi:10.1016/i.cell.2020.10.049 Medline

25. D. Kitamura, J. Roes, R. Kühn, K. Rajewsky, A B cell-deficient mouse by targeted disruption of the membrane exon of the immunoglobulin mu chain gene. Nature 350, 423-426 (1991). doi:10.1038/350423a0 Medline

26. E. S. Winkler, A. L. Bailey, N. M. Kafai, S. Nair, B. T. McCune, J. Yu, J. M. Fox, R. E. Chen, J. T. Earnest, S. P. Keeler, J. H. Ritter, L. I. Kang, S. Dort, A. Robichaud, R. Head, M. J. Holtzman, M. S. Diamond, SARS-CoV-2 infection of human ACE2transgenic mice causes severe lung inflammation and impaired function. Nat. Immunol. 21, 1327-1335 (2020). doi:10.1038/s41590-020-0778-2 Medline

27. J. Zheng, L. R. Wong, K. Li, A. K. Verma, M. E. Ortiz, C. Wohlford-Lenane, M. R. Leidinger, C. M. Knudson, D. K. Meyerholz, P. B. McCray Jr., S. Perlman, COVID-19 treatments and pathogenesis including anosmia in K18-hACE2 mice. Nature 589, 603-607 (2021). doi:10.1038/s41586-020-2943-z Medline

28. A. B. Vogel, I. Kanevsky, Y. Che, K. A. Swanson, A. Muik, M. Vormehr, L. M. Kranz, K. C. Walzer, S. Hein, A. Güler, J. Loschko, M. S. Maddur, A. Ota-Setlik, K. Tompkins, J. Cole, B. G. Lui, T. Ziegenhals, A. Plaschke, D. Eisel, S. C. Dany, S. Fesser, S. Erbar, F. Bates, D. Schneider, B. Jesionek, B. Sänger, A. K. Wallisch, Y. Feuchter, H. Junginger, S. A. Krumm, A. P. Heinen, P. Adams-Quack, J. Schlereth, S. Schille, C. Kröner, R. de la Caridad Güimil Garcia, T. Hiller, L. Fischer, R. S. Sellers, S. Choudhary, O. Gonzalez, F. Vascotto, M. R. Gutman, J. A. Fontenot, S. Hall-Ursone, K. Brasky, M. C. Griffor, S. Han, A. A. H. Su, J. A. Lees, N. L. Nedoma, E. H. Mashalidis, P. V. Sahasrabudhe, C. Y. Tan, D. Pavliakova, G. Singh, C. FontesGarfias, M. Pride, I. L. Scully, T. Ciolino, J. Obregon, M. Gazi, R. Carrion Jr., K. J. Alfson, W. V. Kalina, D. Kaushal, P. Y. Shi, T. Klamp, C. Rosenbaum, A. N. Kuhn, Ö. Türeci, P. R. Dormitzer, K. U. Jansen, U. Sahin, BNT162b vaccines protect rhesus macaques from SARS-CoV-2. Nature 592, 283-289 (2021). doi:10.1038/s41586021-03275-y Medline

29. Y. Zhi, G. P. Kobinger, H. Jordan, K. Suchma, S. R. Weiss, H. Shen, G. Schumer, G. Gao, J. L. Boyer, R. G. Crystal, J. M. Wilson, Identification of murine CD8 T cell epitopes in codon-optimized SARS-associated coronavirus spike protein. Virology 335, 34-45 (2005). doi:10.1016/j.virol.2005.01.050 Medline

30. Z. Zhuang, X. Lai, J. Sun, Z. Chen, Z. Zhang, J. Dai, D. Liu, Y. Li, F. Li, Y. Wang, A Zhu, J. Wang, W. Yang, J. Huang, X. Li, L. Hu, L. Wen, J. Zhuo, Y. Zhang, D. Chen, S. Li, S. Huang, Y. Shi, K. Zheng, N. Zhong, J. Zhao, D. Zhou, J. Zhao, Mapping and role of T cell response in SARS-CoV-2-infected mice. J. Exp. Med. 218, e20202187 (2021). doi:10.1084/jem.20202187 Medline

31. M. J. Mulligan, K. E. Lyke, N. Kitchin, J. Absalon, A. Gurtman, S. Lockhart, K. Neuzil, V. Raabe, R. Bailey, K. A. Swanson, P. Li, K. Koury, W. Kalina, D. Cooper, C. FontesGarfias, P.-Y. Shi, Ö. Türeci, K. R. Tompkins, E. E. Walsh, R. Frenck, A. R. Falsey, P. R. Dormitzer, W. C. Gruber, U. Şahin, K. U. Jansen, Phase I/II study of COVID-19 RNA vaccine BNT162b1 in adults. Nature 586, 589-593 (2020). doi:10.1038/s41586-020-2639-4 Medline

32. E. C. Wall, M. Wu, R. Harvey, G. Kelly, S. Warchal, C. Sawyer, R. Daniels, P. Hobson, E. Hatipoglu, Y. Ngai, S. Hussain, J. Nicod, R. Goldstone, K. Ambrose, S. Hindmarsh, R. Beale, A. Riddell, S. Gamblin, M. Howell, G. Kassiotis, V. Libri, B. Williams, C. Swanton, S. Gandhi, D. L. Bauer, Neutralising antibody activity against SARS-CoV-2 VOCs B.1.617.2 and B.1.351 by BNT162b2 vaccination. Lancet 397, 2331-2333 (2021). doi:10.1016/S0140-6736(21)01290-3 Medline

33. D. Planas, D. Veyer, A. Baidaliuk, I. Staropoli, F. Guivel-Benhassine, M. M. Rajah, C. Planchais, F. Porrot, N. Robillard, J. Puech, M. Prot, F. Gallais, P. Gantner, A. Velay, J. Le Guen, N. Kassis-Chikhani, D. Edriss, L. Belec, A. Seve, L. Courtellemont, H. Péré, L. Hocqueloux, S. Fafi-Kremer, T. Prazuck, H. Mouquet, T. Bruel, E. SimonLorière, F. A. Rey, O. Schwartz, Reduced sensitivity of SARS-CoV-2 variant Delta to antibody neutralization. Nature 596, 276-280 (2021). doi:10.1038/s41586021-03777-9 Medline

34. J. H. Baang, C. Smith, C. Mirabelli, A. L. Valesano, D. M. Manthei, M. A. Bachman, C. E. Wobus, M. Adams, L. Washer, E. T. Martin, A. S. Lauring, Prolonged Severe Acute Respiratory Syndrome Coronavirus 2 Replication in an Immunocompromised Patient. J. Infect. Dis. 223, 23-27 (2021). doi:10.1093/infdis/iiaa666 Medline

35. E. Mira, O. A. Yarce, C. Ortega, S. Fernández, N. M. Pascual, C. Gómez, M. A. Alvarez, I. J. Molina, R. Lama, M. Santamaria, Rapid recovery of a SARS-CoV-2- infected $X$-linked agammaglobulinemia patient after infusion of COVID-19 convalescent plasma. J. Allergy Clin. Immunol. Pract. 8, 2793-2795 (2020). doi:10.1016/i.jaip.2020.06.046 Medline

36. A. Park, A. Iwasaki, Type I and Type III Interferons - Induction, Signaling, Evasion, and Application to Combat COVID-19. Cell Host Microbe 27, 870-878 (2020). doi:10.1016/i.chom.2020.05.008 Medline

37. C. Rydyznski Moderbacher, S. I. Ramirez, J. M. Dan, A. Grifoni, K. M. Hastie, D. Weiskopf, S. Belanger, R. K. Abbott, C. Kim, J. Choi, Y. Kato, E. G. Crotty, C. Kim, S. A. Rawlings, J. Mateus, L. P. V. Tse, A. Frazier, R. Baric, B. Peters, J. Greenbaum, E. Ollmann Saphire, D. M. Smith, A. Sette, S. Crotty, Antigen-Specific Adaptive Immunity to SARS-CoV-2 in Acute COVID-19 and Associations with Age and Disease Severity. Cell 183, 996-1012.e19 (2020). doi:10.1016/i.cell.2020.09.038 Medline

38. A. T. Tan, M. Linster, C. W. Tan, N. Le Bert, W. N. Chia, K. Kunasegaran, Y. Zhuang, C. Y. L. Tham, A. Chia, G. J. D. Smith, B. Young, S. Kalimuddin, J. G. H. Low, D. Lye, L. F. Wang, A. Bertoletti, Early induction of functional SARS-CoV-2-specific T cells associates with rapid viral clearance and mild disease in COVID-19 patients. Cell Rep. 34, 108728 (2021). doi:10.1016/i.celrep.2021.108728 Medline

39. T. Sekine, A. Perez-Potti, O. Rivera-Ballesteros, K. Strålin, J. B. Gorin, A. Olsson, S. Llewellyn-Lacey, H. Kamal, G. Bogdanovic, S. Muschiol, D. J. Wullimann, T. Kammann, J. Emgård, T. Parrot, E. Folkesson, O. Rooyackers, L. I. Eriksson, J. I. Henter, A. Sönnerborg, T. Allander, J. Albert, M. Nielsen, J. Klingström, S. Gredmark-Russ, N. K. Björkström, J. K. Sandberg, D. A. Price, H. G. Ljunggren, S. Aleman, M. Buggert; Karolinska COVID-19 Study Group, Robust T Cell Immunity in Convalescent Individuals with Asymptomatic or Mild COVID-19. Cell 183, 158168.e14 (2020). doi:10.1016/i.cell.2020.08.017 Medline

40. A. Wajnberg, F. Amanat, A. Firpo, D. R. Altman, M. J. Bailey, M. Mansour, M. McMahon, P. Meade, D. R. Mendu, K. Muellers, D. Stadlbauer, K. Stone, S. Strohmeier, V. Simon, J. Aberg, D. L. Reich, F. Krammer, C. Cordon-Cardo, Robust neutralizing antibodies to SARS-CoV-2 infection persist for months. Science 370, 1227-1230 (2020). doi:10.1126/science.abd7728 Medline

41. C. Gaebler, Z. Wang, J. C. C. Lorenzi, F. Muecksch, S. Finkin, M. Tokuyama, A. Cho, M. Jankovic, D. Schaefer-Babajew, T. Y. Oliveira, M. Cipolla, C. Viant, C. O. Barnes, Y. Bram, G. Breton, T. Hägglöf, P. Mendoza, A. Hurley, M. Turroja, K. Gordon, K. G. Millard, V. Ramos, F. Schmidt, Y. Weisblum, D. Jha, M. Tankelevich, G. MartinezDelgado, J. Yee, R. Patel, J. Dizon, C. Unson-O'Brien, I. Shimeliovich, D. F. Robbiani, Z. Zhao, A. Gazumyan, R. E. Schwartz, T. Hatziioannou, P. J. Bjorkman, S. Mehandru, P. D. Bieniasz, M. Caskey, M. C. Nussenzweig, Evolution of antibody immunity to SARS-CoV-2. Nature 591, 639-644 (2021). doi:10.1038/s41586021-03207-w Medline

42. W. E. Matchett, V. Joag, J. M. Stolley, F. K. Shepherd, C. F. Quarnstrom, C. K. Mickelson, S. Wijeyesinghe, A. G. Soerens, S. Becker, J. M. Thiede, E. Weyu, S. D. O'Flanagan, J. A. Walter, M. N. Vu, V. D. Menachery, T. D. Bold, V. Vezys, M. K. Jenkins, R. A. Langlois, D. Masopust, Nucleocapsid Vaccine Elicits SpikeIndependent SARS-CoV-2 Protective Immunity. J. Immunol. 207, 376-379 (2021). doi:10.4049/iimmunol.2100421 Medline

43. K. H. Dinnon 3rd, S. R. Leist, A. Schäfer, C. E. Edwards, D. R. Martinez, S. A. Montgomery, A. West, B. L. Yount Jr., Y. J. Hou, L. E. Adams, K. L. Gully, A. J. Brown, E. Huang, M. D. Bryant, I. C. Choong, J. S. Glenn, L. E. Gralinski, T. P. Sheahan, R. S. Baric, A mouse-adapted model of SARS-CoV-2 to test COVID-19 countermeasures. Nature 586, 560-566 (2020). doi:10.1038/s41586-0202708-8 Medline

44. J. Zhao, J. Zhao, A. K. Mangalam, R. Channappanavar, C. Fett, D. K. Meyerholz, S. Agnihothram, R. S. Baric, C. S. David, S. Perlman, Airway Memory CD4(+) T Cells Mediate Protective Immunity against Emerging Respiratory Coronaviruses. Immunity 44, 1379-1391 (2016). doi:10.1016/j.immuni.2016.05.006 Medline

45. C. Lucas, C. B. F. Vogels, I. Yildirim, J. E. Rothman, P. Lu, V. Monteiro, J. R. Gelhausen, M. Campbell, J. Silva, A. Tabachikova, M. C. Muenker, M. I. Breban, J. R. Fauver, S. Mohanty, J. Huang, Impact of circulating SARS-CoV-2 variants on mRNA vaccine-induced immunity in uninfected and previously infected individuals. medRxiv, 2021.2007.2014.21260307 (2021).

46. D. S. Khoury, D. Cromer, A. Reynaldi, T. E. Schlub, A. K. Wheatley, J. A. Juno, K. Subbarao, S. J. Kent, J. A. Triccas, M. P. Davenport, Neutralizing antibody levels are highly predictive of immune protection from symptomatic SARS-CoV-2 infection. Nat. Med. 27, 1205-1211 (2021). doi:10.1038/s41591-021-01377-8 
Medline

47. F. Amanat, D. Stadlbauer, S. Strohmeier, T. H. O. Nguyen, V. Chromikova, M. McMahon, K. Jiang, G. A. Arunkumar, D. Jurczyszak, J. Polanco, M. BermudezGonzalez, G. Kleiner, T. Aydillo, L. Miorin, D. S. Fierer, L. A. Lugo, E. M. Kojic, J. Stoever, S. T. H. Liu, C. Cunningham-Rundles, P. L. Felgner, T. Moran, A. GarcíaSastre, D. Caplivski, A. C. Cheng, K. Kedzierska, O. Vapalahti, J. M. Hepojoki, V. Simon, F. Krammer, A serological assay to detect SARS-CoV-2 seroconversion in humans. Nat. Med. 26, 1033-1036 (2020). doi:10.1038/s41591-020-0913-5 Medline

48. V. A. Avanzato, K. Y. Oguntuyo, M. Escalera-Zamudio, B. Gutierrez, M. Golden, S. L. Kosakovsky Pond, R. Pryce, T. S. Walter, J. Seow, K. J. Doores, O. G. Pybus, V. J. Munster, B. Lee, T. A. Bowden, A structural basis for antibody-mediated neutralization of Nipah virus reveals a site of vulnerability at the fusion glycoprotein apex. Proc. Natl. Acad. Sci. U.S.A. 116, 25057-25067 (2019). doi:10.1073/pnas.1912503116 Medline

49. J. S. Chen, R. D. Chow, E. Song, T. Mao, B. Israelow, K. Kamath, J. Bozekowski, W. A. Haynes, R. B. Filler, B. L. Menasche, J. Wei, M. M. Alfajaro, W. Song, L. Peng, L. Carter, J. S. Weinstein, U. Gowthaman, S. Chen, J. Craft, J. C. Shon, A. Iwasaki, C. B. Wilen, S. C. Eisenbarth, High-affinity, neutralizing antibodies to SARS-CoV-2 can be made in the absence of $\mathrm{T}$ follicular helper cells. bioRxiv, 2021.2006.2010.447982 (2021).

50. J. Wei, M. M. Alfajaro, P. C. DeWeirdt, R. E. Hanna, W. J. Lu-Culligan, W. L. Cai, M. S. Strine, S. M. Zhang, V. R. Graziano, C. O. Schmitz, J. S. Chen, M. C. Mankowski, R. B. Filler, N. G. Ravindra, V. Gasque, F. J. de Miguel, A. Patil, H. Chen, K. Y. Oguntuyo, L. Abriola, Y. V. Surovtseva, R. C. Orchard, B. Lee, B. D. Lindenbach, K. Politi, D. van Dijk, C. Kadoch, M. D. Simon, Q. Yan, J. G. Doench, C. B. Wilen, Genome-wide CRISPR Screens Reveal Host Factors Critical for SARS-CoV-2 Infection. Cell 184, 76-91.e13 (2021). doi:10.1016/i.cell.2020.10.028 Medline

Acknowledgments: We thank H. Dong and M. Linehan for technical and logistical assistance. We thank Patrick Roberts and Bryan Cretella from the Yale Health Pharmacy for providing residual vaccine used in this study. We thank Craig Wilen, Jin Wei, and Jennifer Chen for technical assistance and providing reagents. We thank Carolina Lucas for technical expertise and for critical feedback on the manuscript. We thank Sidi Chen and Lei Peng for kindly providing the plasmid to express SARS-CoV-2 B.1.351 Spike. We thank Barney Graham (NIH-VRC) for kindly providing VeroE6 cells overexpressing ACE2 and TMPRSS2. We thank the NIH Tetramer Core Facility for providing PE labeled SARS-CoV-2 S 539-546 tetramer (H-2K(b)). We also give special recognition to Ben Fontes and the Yale EH\&S Department for their on-going assistance in safely conducting biosafety level 3 research. Funding: This work was supported by NIH grants T32AI007517 and K08Al163493 to B.I., T32AI007019 to T.M., T32GM007205 and F30CA239444 to E.S., and R01Al157488 to A.I. Support for this work was also provided by Fast Grant from Emergent Ventures at Mercatus Center, the Ludwig Family Foundation, and the G. Harold and Leila Y. Mathers Foundation to A.I. A.I. is an investigator of the Howard Hughes Medical Institute. Author contributions: B.I., S.B.O., and A.I. conceived of and designed the study. B.I, T.M., J.K., and E.S., performed investigation, B.M. generated critical reagents. B.I. and T.M. performed data analysis and visualization. Manuscript written by B.I. and A.I. All authors discussed the result and reviewed and commented on the manuscript. Competing interests: Al served as a consultant for Spring Discovery and Adaptive Biotechnologies. Data and materials availability: All data needed to evaluate the conclusions in the paper are present in the paper or the Supplementary Materials. Further information and requests for resources and reagents should be directed to corresponding author A.I. This work is licensed under a Creative Commons Attribution 4.0 International (CC BY 4.0) license, which permits unrestricted use, distribution, and reproduction in any medium, provided the original work is properly cited. To view a copy of this license, visit https://creativecommons.org/licenses/by/4.0/. This license does not apply to figures/photos/artwork or other content included in the article that is credited to a third party; obtain authorization from the rights holder before using such material.

Submitted 14 July 2021

Accepted 24 August 2021

Published First Release 2 September 2021

10.1126/sciimmunol.abl4509 
Fig. 1. SARS-CoV-2 clearance in $\mathrm{RAG}^{-/-}$ and $\mu \mathrm{MT}$ mice. (A) Experimental schematic. C57Bl/6J (WT), B6.129S7-

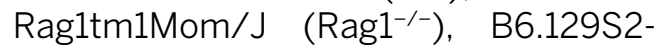
Ighmtm1Cgn/J ( $\mu \mathrm{MT}$ ) mice were intratracheally transduced with $10^{11} \mathrm{GC}$ (genomic copies) of AAV encoding human ACE2 (AAV-hACE2) and allowed to recover for 14 days. Mice were then infected with WA1 strain SARS-CoV-2 at $10^{6}$ PFU intranasally and lungs samples are collected at 2-, 4-, 7-, and 14-days post infection and assessed by (B) quantitative $\mathrm{PCR}$ and (C) plaque assay. Values noted on $X$-axis (C) indicate numbers of samples tested positive/number of samples. LD (limit of detection). Individual values noted as dots and bars indicate mean \pm SEM from 3-8 samples of two-three independent experiments. $P$ values were calculated by two-way ANOVA with Tukey's multiple comparison. ${ }^{*}, \mathrm{P}<0.05 ;{ }^{* *}, \mathrm{P}<0.01$; ${ }^{* * *}$, $\mathrm{P}<0.001,{ }^{* * * *}, \mathrm{P}<0.001$
A.
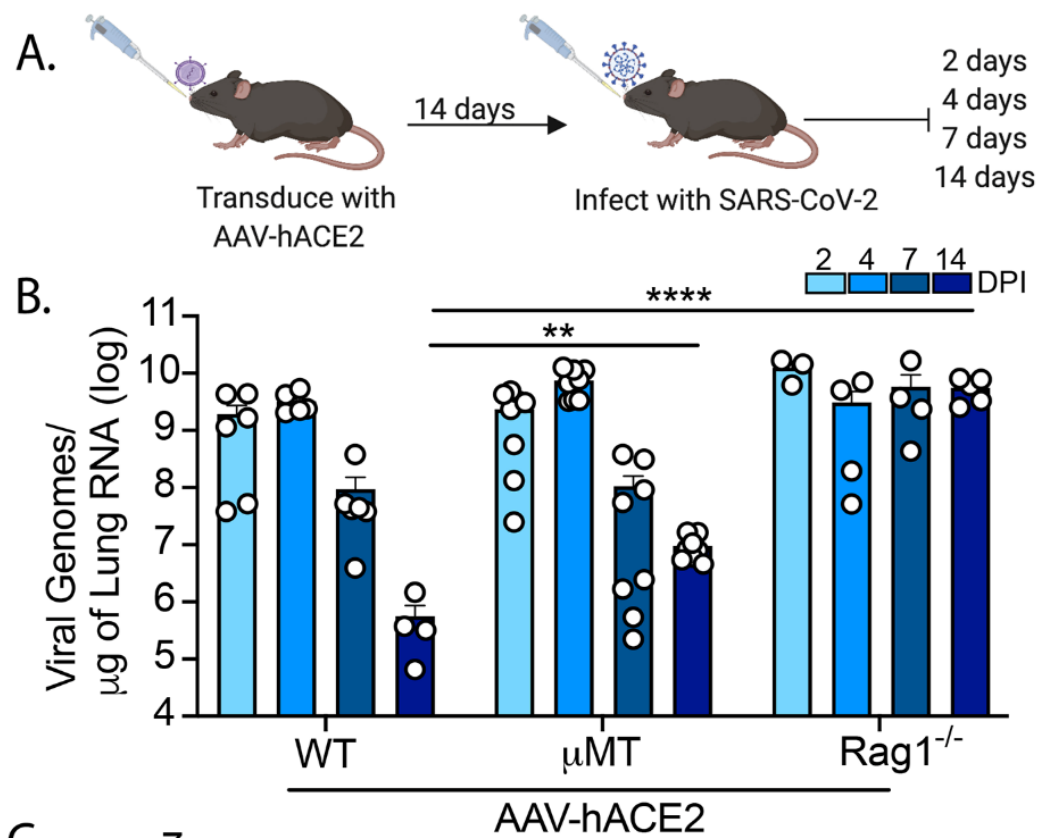

C.

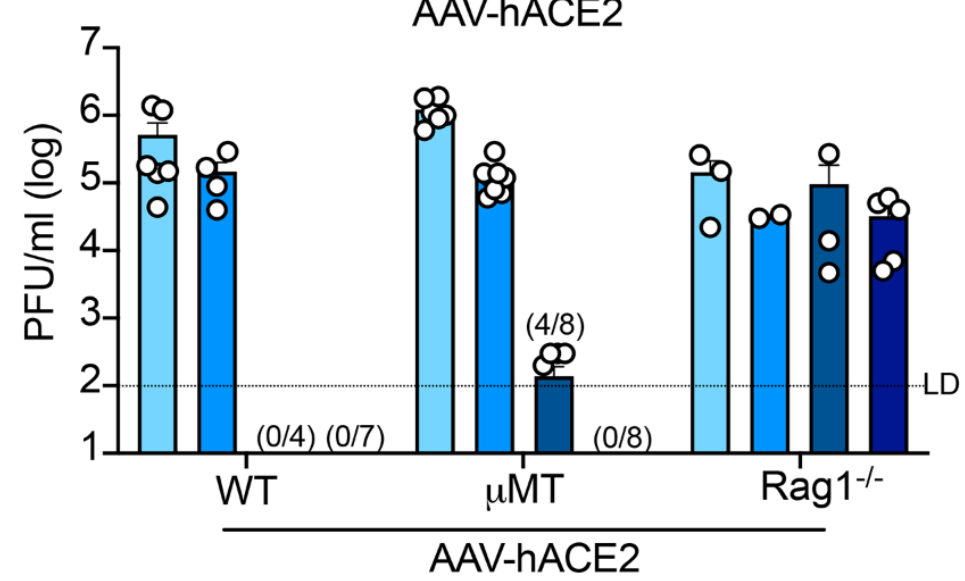




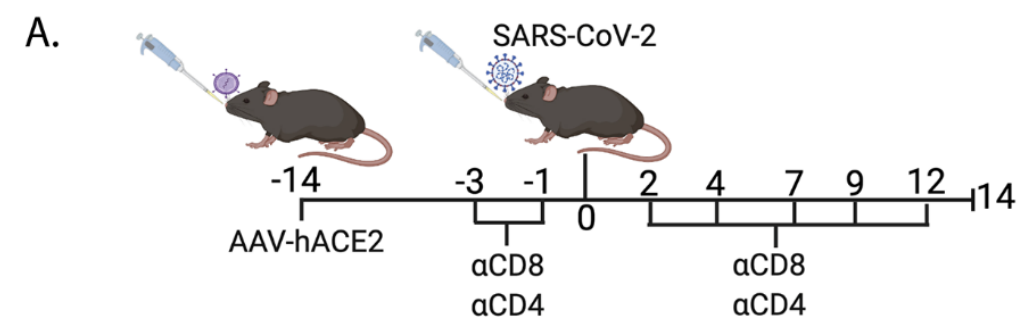

B.

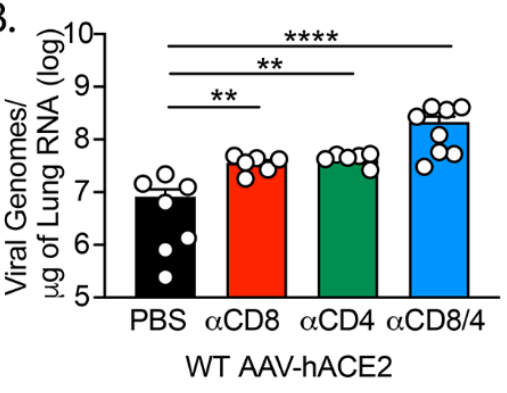

D.

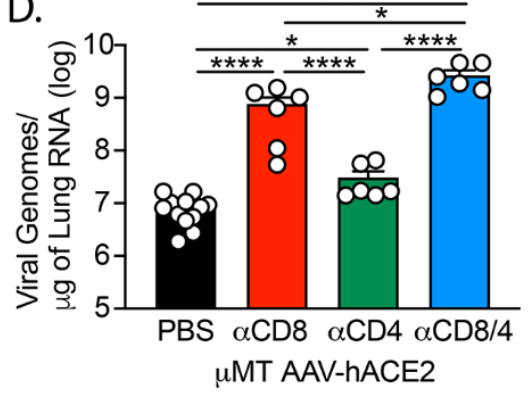

C.
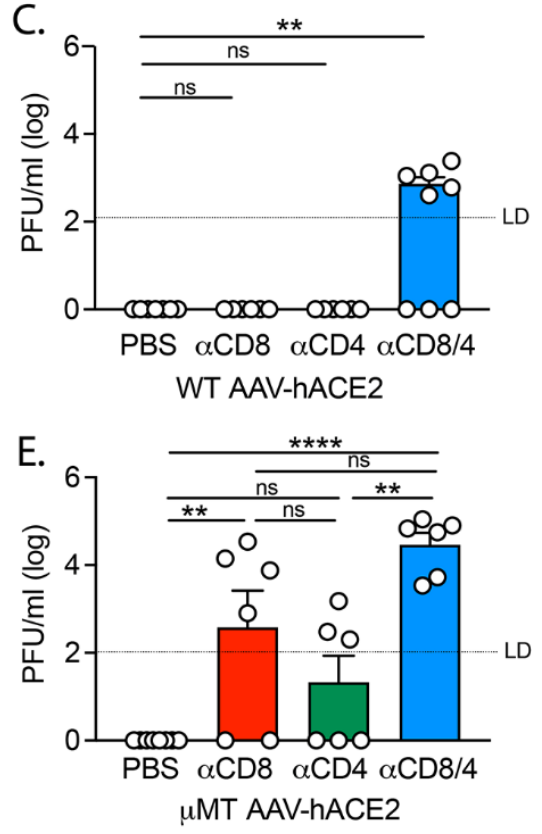

Fig. 2. SARS-CoV-2 clearance in CD4 $4^{+}$and $C D 8^{+} T$ cell depleted $W T$ and HMT mice. (A) Experimental design. AAV-hACE2 transduced WT (B, C) and $\mu \mathrm{MT}(\mathrm{D}, \mathrm{E})$ were injected (intraperitoneal) with $200 \mathrm{mg}$ anti-mouse CD8a (clone 2.43) or 200mg anti-mouse CD4 (clone GK1.5) starting at 3 days prior to infection and given every 2 to 3 days as indicated until 12 DPI. Mice were infected with WA1 strain SARS-CoV-2 at $10^{6}$ PFU intranasally and lungs were collected at $14 \mathrm{DPI}$ and assessed by quantitative PCR (B,D) and plaque assay (C,E). Individual values noted as dots and bars indicate mean \pm SEM from 6-12 samples of two-three independent experiments. $P$ values were calculated by one-way ANOVA with Tukey's multiple comparison. *, $\mathrm{P}<0.05 ;{ }^{* *}, \mathrm{P}<0.01$; ***, $\mathrm{P}<0.001$, $* * * *, P<0.001$ 


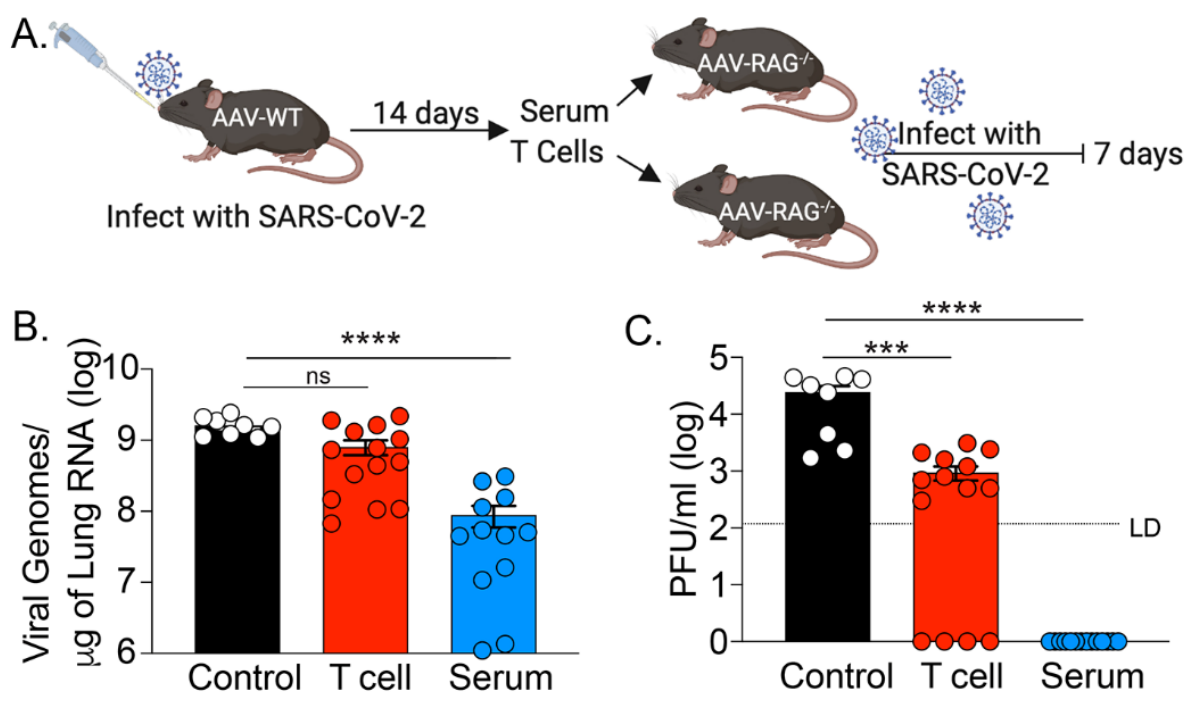

Fig. 3. Infection of $\mathrm{RAG}^{-/-}$mice after adoptive transfer of serum or T cells. (A) Experimental design. AAV-hACE2 transduced WT mice were infected with $10^{6}$ PFU WA1 strain SARS-CoV-2 via intranasal route. $14 \mathrm{DPI}$ serum and mediastinal lymph node were collected. Total $T$ cells were isolated by magnetic separation. AAV-hACE2 transduced $\mathrm{RAG}^{-/}$mice received adoptive transfer of PBS (control), serum (200ml), or $2 \times 10^{6}$ total T cells at one day prior to infection with $10^{6}$ PFU WA1 strain SARS-CoV-2. Lungs were collected at $7 \mathrm{DPI}$ and assessed for (B) viral RNA by quantitative PCR and for (C) viral titer by plaque assay. Individual values noted as dots and bars indicate mean \pm SEM from 8-12 samples of two independent experiments. $P$ values were calculated by one-way ANOVA with Tukey's multiple comparison. ${ }^{*}, \mathrm{P}<0.05 ;{ }^{* *}, \mathrm{P}<0.01 ;{ }^{* * *}, \mathrm{P}<0.001,{ }^{* * * *}, \mathrm{P}<0.001$ 
Fig. 4. Dose dependent antibody response to mRNA vaccine reveals correlate of protection in $\mathrm{K} 18$ mice. (A) B6.Cg-Tg(K18-ACE2)2Prlmn/J (K18-hACE2) mice received a single intramuscular injection of Pfizer/BioNTech BNT162b2 mRNA vaccine at the indicated doses. (B) 28 days post injection serum samples were harvested and anti-SARS-CoV-2 anti S1 antibody concentration was measured by ELISA at indicated dilutions (LN-natural log transformed). At 30 days post vaccination mice were challenged with $4 \times 10^{5}$ PFU WA1 SARSCoV-2. (C) Weight loss (please see raw data file for calculated $p$ values) and (D) Kaplan-Meier survival curve of animals monitored for 15 DPI. P values were calculated by Log-rank (MantelCox) test. ${ }^{*}, \mathrm{P}<0.05$; **, $\mathrm{P}<0.01$. Individual preinfection serum from (B) was used to calculate (E) S1 IgG area under the curve (AUC) or (G) IC50 with VSV pseudovirus neutralization assay and plotted against weight change at 6 DPI (Rs=Spearman correlation coefficient) and $P$ values indicated. Differences in $(F)$ preinfection S1 IgG AUC and $(\mathrm{H})$ VSV pseudovirus neutralization IC50 between mice that survived and mice that died from infection. Logistic regression (Prism) was used to calculate $50 \%$ survival titers indicated by dotted line. $\mathrm{N}=5$ mice per condition.
A.

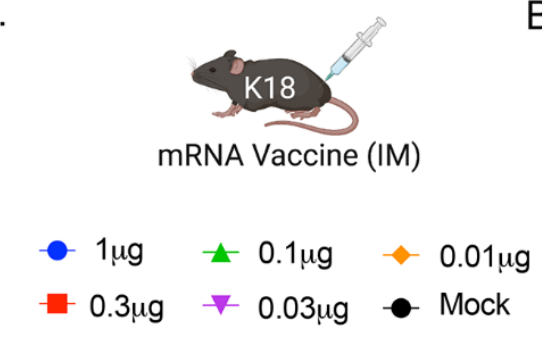

B.
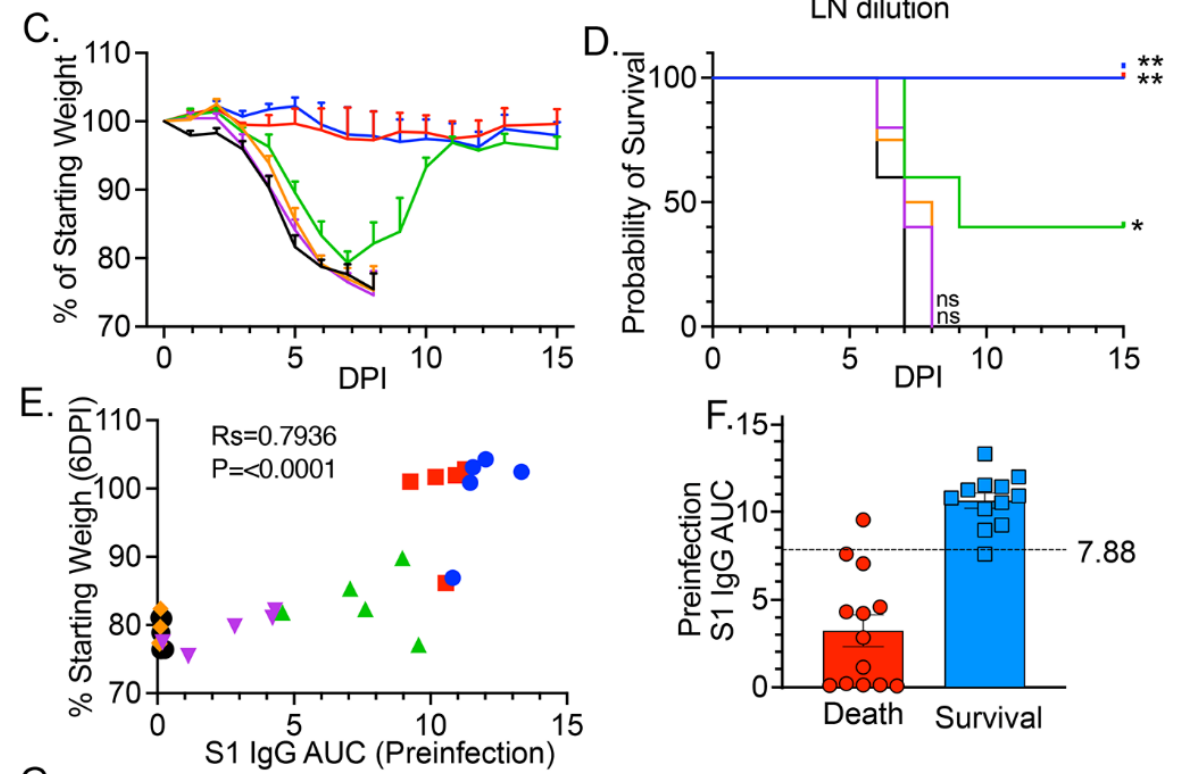

G.

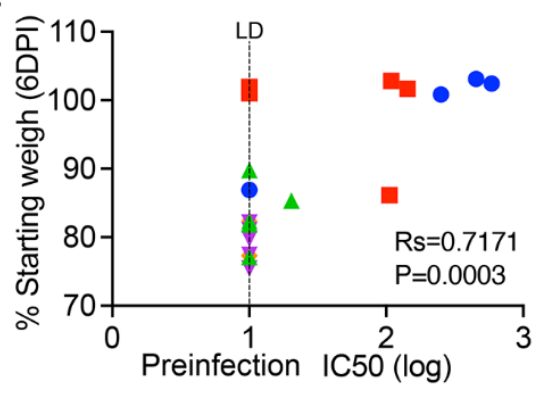

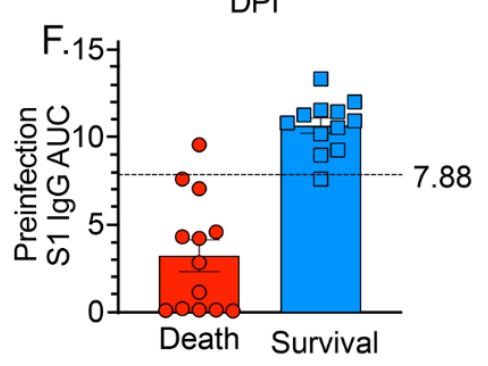

$\mathrm{H}$.
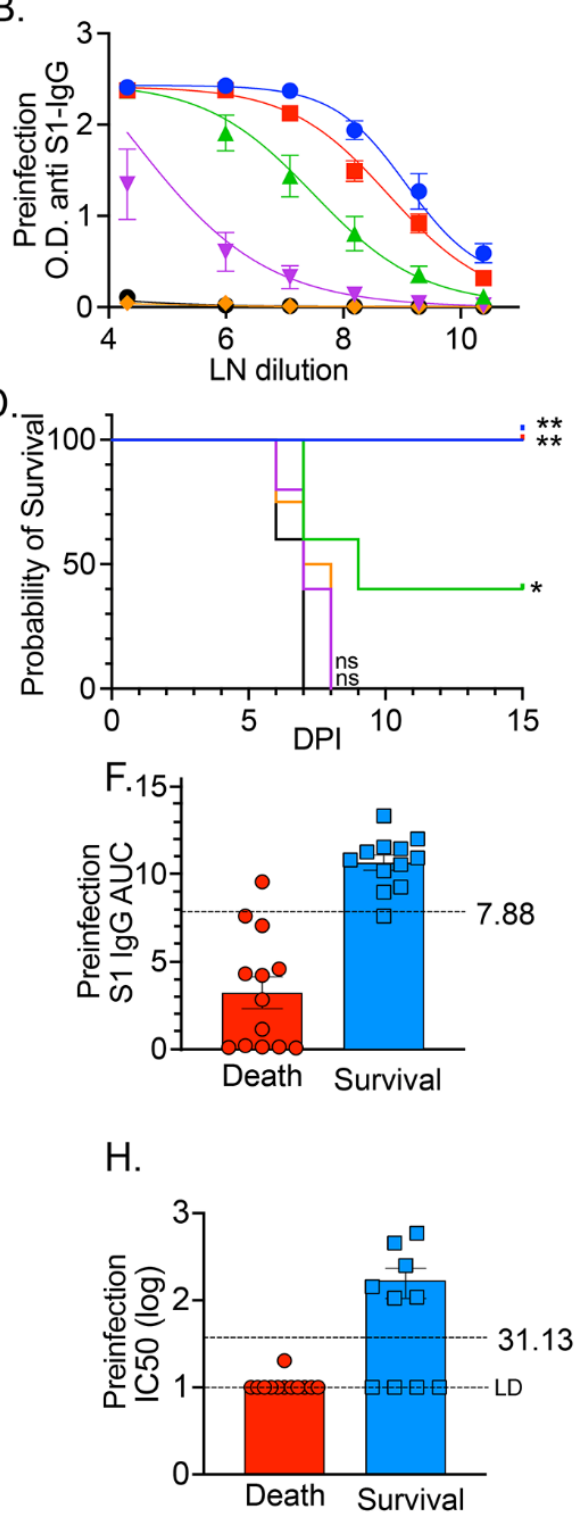

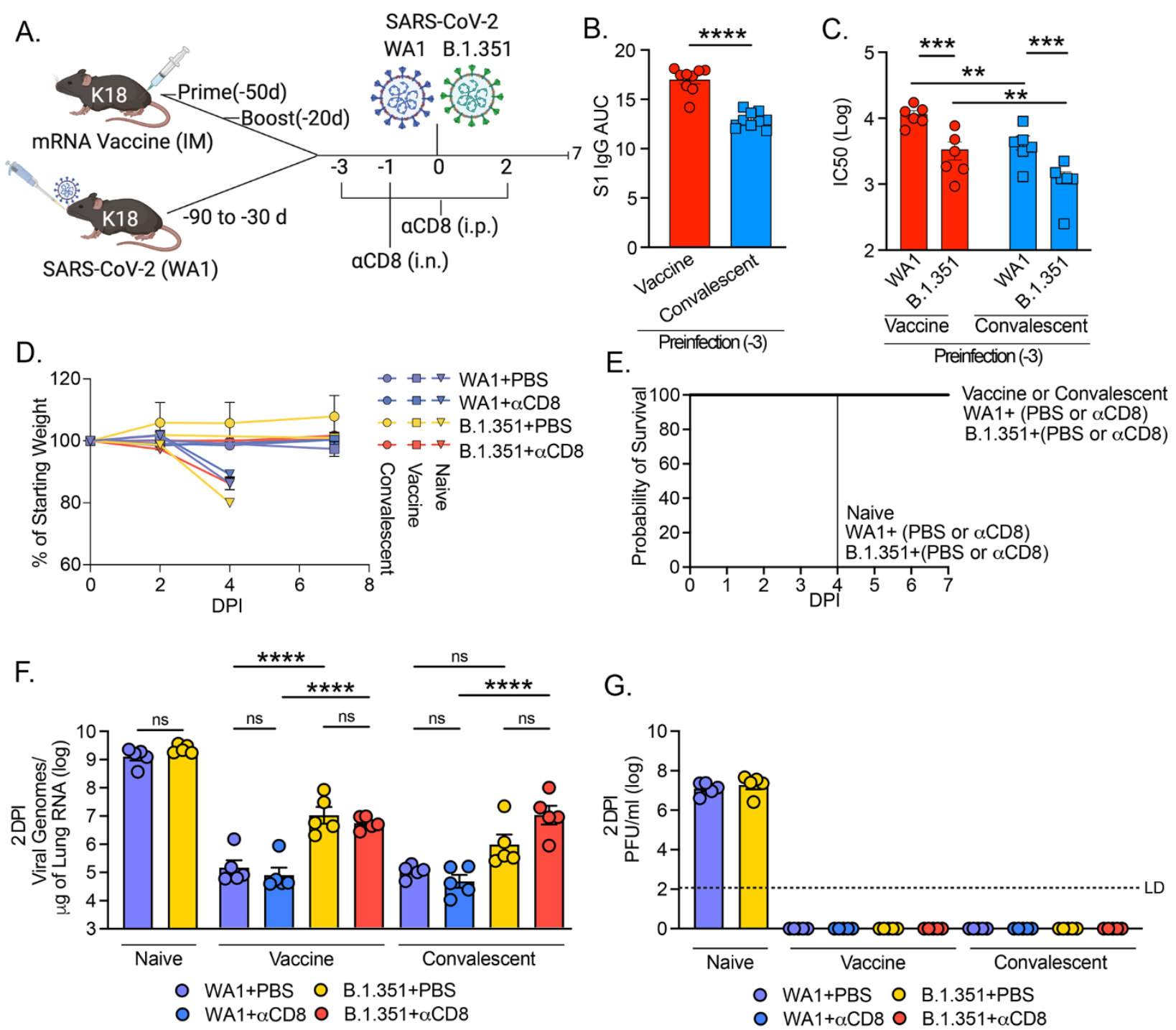

Fig. 5. Response to homologous and B.1.351 challenge of convalescent and mRNA vaccinated mice.

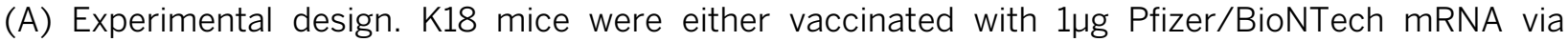
intramuscular injection via prime/boost with a 30-day interval, or infected with 500 PFU WA1 strain SARS-CoV-2 via intranasal administration once. Preinfection serum was collected 3 days prior to infection and (B) anti-SARS-CoV-2 antibody titer was assessed by ELISA, plotted as AUC, and (C) VSV pseudovirus neutralization assay performed with either pseudovirus expressing WA1 or B.1.351 spike and plotted as log IC50. Mice were injected (i.p.) with 200mg anti-mouse CD8a (clone 2.43) or PBS (control) at 3 and 1 days prior to infection, and 2 days post infection, and mice received 100mg antimouse CD8a or PBS via intranasal administration at 1 day prior to infection. Mice were infected with $4 \times 10^{5}$ PFU of with homologous strain (WA1) or VOC (B.1.351) via intranasal route and euthanized either 2-, 4- or 7-days post infection. (D) Weight loss and (E) Kaplan-Meier survival curve were monitored for 7 DPI. (F) Viral RNA was assessed by quantitative PCR and $(G)$ viral titer assessed by plaque assay at 2 DPI. LD (limit of detection). Individual values noted as dots and bars indicate mean \pm SEM from $n=5$ samples per condition. P values were calculated by one-way ANOVA with Tukey's multiple comparison, except in (B) where a Student's $t$ test was used and (C) where two-way ANOVA with Tukey's multiple comparison was used. ${ }^{*}, \mathrm{P}<0.05 ;{ }^{* *}, \mathrm{P}<0.01 ;{ }^{* *}, \mathrm{P}<0.001$, ${ }^{* * *}, \mathrm{P}<0.001$ 